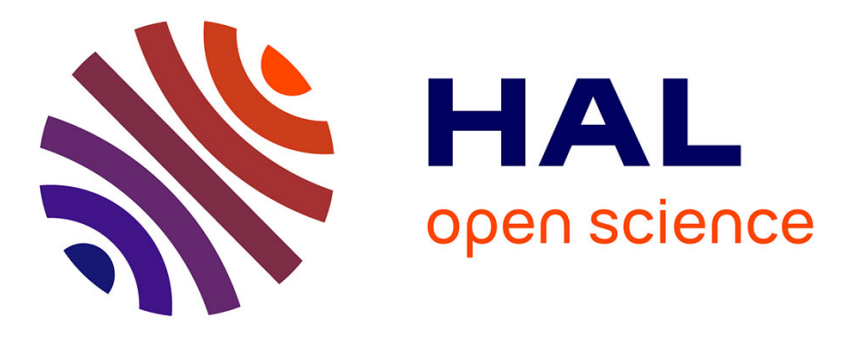

\title{
Modern drought conditions in western Sahel unprecedented in the past 1600 years
}

Matthieu Carré, Moufok Azzoug, Paul Zaharias, Abdoulaye Camara, Rachid

Cheddadi, Manuel Chevalier, Denis Fiorillo, Amadou Thierno Gaye, Serge Janicot, Myriam Khodri, et al.

\section{To cite this version:}

Matthieu Carré, Moufok Azzoug, Paul Zaharias, Abdoulaye Camara, Rachid Cheddadi, et al.. Modern drought conditions in western Sahel unprecedented in the past 1600 years. Climate Dynamics, 2019, 52 (3-4), pp.1949-1964. 10.1007/s00382-018-4311-3 . hal-02349321

\section{HAL Id: hal-02349321 \\ https://hal.science/hal-02349321}

Submitted on 5 Nov 2019

HAL is a multi-disciplinary open access archive for the deposit and dissemination of scientific research documents, whether they are published or not. The documents may come from teaching and research institutions in France or abroad, or from public or private research centers.
L'archive ouverte pluridisciplinaire HAL, est destinée au dépôt et à la diffusion de documents scientifiques de niveau recherche, publiés ou non, émanant des établissements d'enseignement et de recherche français ou étrangers, des laboratoires publics ou privés. 


\section{Modern drought conditions in western Sahel unprecedented in the past 1600 years}

\section{Authors:}

Matthieu Carré ${ }^{1,2 *}$ (ORCID ID: 0000-0001-8178-7316), Moufok Azzoug ${ }^{3}$, Paul Zaharias ${ }^{4}$, Abdoulaye Camara ${ }^{5}$, Rachid Cheddadi ${ }^{6}$, Manuel Chevalier ${ }^{7}$, Denis Fiorillo ${ }^{8}$, Amadou T. Gaye $^{9}$, Serge Janicot ${ }^{1}$, Myriam Khodri ${ }^{1}$, Alban Lazar ${ }^{1}$, Claire E. Lazareth ${ }^{1}$, Juliette Mignot ${ }^{1}$, Nancy Mitma Garcia ${ }^{6}$, Nicolas Patris ${ }^{10}$, Océane Perrot ${ }^{6}$, Malick Wade ${ }^{11}$.

\section{Affiliations:}

${ }^{1}$ Sorbonne Universités (UPMC, Univ Paris 06)-CNRS-IRD-MNHN, LOCEAN Laboratory, Paris, France.

${ }^{2}$ CIDIS-LID-Facultad de Ciencias y Filosofía-Universidad Peruana Cayetano Heredia, Lima, Perú.

${ }^{3}$ Département de génie des procédés, faculté de technologie, Université de Bejaia, 06000 Bejaia, Algeria.

${ }^{4}$ ISYEB - UMR 7205 - CNRS, MNHN, UPMC (Université Paris 6), EPHE - Muséum national d'Histoire naturelle, Sorbonne Universités, Paris, France.

${ }^{5}$ Institut Fondamental d'Afrique Noire, Université Cheikh Anta Diop, Dakar, Senegal.

${ }^{6}$ CNRS-UM-IRD-EPHE, Institut des Sciences de l'Evolution de Montpellier, Montpellier, France.

${ }^{7}$ Institut des Dynamiques de la Surface Terrestre, University of Lausanne, Switzerland. ${ }^{8}$ CNRS-MNHN, Archéozoologie, archéobotanique: sociétés, pratiques et environnements, Paris, France.

${ }^{9}$ Institut polytechnique, Université Cheikh Anta Diop, Dakar, Senegal.

${ }^{10}$ IRD-CNRS-UM, Hydrosciences Montpellier, Montpellier, France.

${ }^{11}$ Laboratoire de Physique de l'Atmosphere et de l'Ocean Simeon Fongang, Université Cheikh Anta Diop, Dakar, Senegal.

*Correspondence to: matthieu.carre @locean-ipsl.upmc.fr;

Tel.: +33629104384 / +51938 818475 


\section{Abstract}

As climate model uncertainties remain very large for future rainfall in the Sahel, a multicentennial perspective is required to assess the situation of current Sahel climate in the context of global warming. We present here the first record of hydroclimatic variability over the past 1600 years in Senegal, obtained from stable oxygen isotope analyses $\left(\delta^{18} \mathrm{O}\right)$ in archaeological shell middens from the Saloum Delta. During the preindustrial period, the region was relatively humid, with maximum humidity reached during the period from AD 1500 to AD 1800, referred to as the Little Ice Age. A significant negative link is observed at the centennial scale between global temperature and humidity in the Sahel that is at odds with the expected effects of latitudinal shifts of the intertropical convergence zone during the last millennium. In the context of the past 1600 years, the Western Sahel appears to be experiencing today unprecedented drought conditions. The rapid aridification that started $c a$. AD 1800 and the recent emergence of Sahel drought from the natural variability point to an anthropogenic forcing of Sahel drying trend. This new long-term perspective suggests that the recovery of Sahel rainfall in the last decade may only result from short-term internal variability, and supports climate models that predict an increase of Sahel drought under future greenhouse climate.

Keywords: West African Monsoon, Climate Change, Paleoclimate, Shell middens 


\section{Introduction}

Precipitation in the Sahel declined by $\sim 30 \%$ in the 1960s, initiating a severe multidecadal drought that represents one of the most significant climate change episodes in the global instrumental record (Christensen et al. 2013), with devastating socio-economic impacts. The contributions of global warming and land use to this event, however, are still not clearly understood, partly because of the underperformance of climate models in the simulation of the West African Monsoon (WAM), and partly because of the shortness of the instrumental record (Biasutti 2013). Rain gauge data in the Sahel start in AD 1851 in Saint Louis, Senegal, but regional data is generally considered robust only after AD 1900 (Nicholson et al. 2012). In the instrumental record, the Sahel climate has been dominated by multidecadal variability which may mask longer-term trends. Assessing current trends in Sahel rainfall and determining the potential role of anthropogenic activities in this climatically vulnerable region requires a multi-centennial perspective of natural variability, which is so far lacking in this region (Nash et al. 2016). The closest continuous record documenting hydroclimate change in the past two millennia comes from Lake Bosumtwi, Ghana (Shanahan et al. 2009), which is not located in the Sahel but in the convection area of the WAM.

In this study, we use oxygen isotope ratios $\left(\delta^{18} \mathrm{O}\right)$ of Senilia senilis shells from the Saloum Delta in Senegal, to construct the first record of centennial variability of the hydrologic balance of the Western Sahel, spanning the last 1600 years. The people of the region have long depended on S. senilis as a staple food, as evidenced by the massive archaeological shell middens (up to $15 \mathrm{~m}$ high) that have been accumulated throughout the Delta (Thilmans and Descamps 1982; Hardy et al. 2016). By virtue of their size and antiquity, these middens present a unique opportunity to obtain diachronic records of hydrological change. 
The Saloum Delta is a mangrove estuary with a small catchment basin, disconnected from the Senegal River or the Gambia River catchment basins. The extremely steep latitudinal precipitation gradient at this location makes the Saloum estuary highly sensitive to changes in the WAM (Fig. 1). Although a contrasted evolution of rainfall in central and western Sahel has been described in the past decade, and projected in the future (Biasutti 2013), instrumental observations show a remarkable coherence of precipitation for the whole of the Sahel (Nicholson 2014) and in particular a strong correlation between precipitation in the Saloum Delta and the Sahel (Wade et al. 2015) (Fig. 1). Assuming the stationarity of this spatial coherence, we consider that our record is largely representative of conditions in at least the western Sahel region and potentially the whole Sahel band.

\section{Material and methods}

\subsection{Bivalve shells}

Modern shells of Senilia senilis were collected live on intertidal mud flats in five locations distributed across the mangrove delta close to the archaeological sites (Fig. 1). Fossil shells from sites A10, A12, and A49 were collected on the surface of those shell middens. In Dioron Boumak shell midden, the full stratigraphy of the shell accumulation could be sampled in the outcrop produced by tidal erosion (Fig. 2). In Tioupane and Diofandor, we sampled the middens from the surface to depths of 5.50 and $1.15 \mathrm{~m}$ respectively, in outcrops produced by ancient exploitation for lime production. The shell middens were almost exclusively composed of S. senilis shells, with infilling composed of sand, silts, and ashes, and had therefore a very poor cohesive structure (Fig. 2). After cleaning the outcrops, the accumulations were divided into a continuous vertical sequence of 
stratigraphic sections. About 30 shells were collected on the field in each section from the surface to the bottom. Subsequently, subsamples of 1 to 7 shells per section were selected in the lab based on shell size and preservation. Therefore, each shell comes from a depth interval and as such, it represents a short $\sim 2-10$-yr window ( $\sim 5$ years in average) randomly drawn from the time period when the section was accumulated. The depth, thickness and the number of shells analyzed are indicated for each stratigraphic layer in the depth-age model plots (Fig. $3)$.

Shell preservation was tested by observing the aragonite microstructure in the hinge of a subsample of shells from Dioron Boumak using a Scanning Electronic Microscope (SEM). Images revealed a perfectly preserved cross-lamellar structure (Fig. 4C). To guarantee a well preserved isotopic signal, aragonite powder samples for isotopic analyses were collected in cross section to avoid surface alteration, in the hinge, which is the thickest and best preserved part (Fig. 4A). For shells that were not observed by SEM, preservation was evaluated by optical microscope observation of the polished cross sections. Aragonite opacity and the fact that growth lines could be observed in every part of the shells are complementary evidence that shells and their original isotopic composition were well preserved.

\subsection{Chronology}

For Dioron Boumak, Tioupane, and Diofandor, depth-age models were calculated from radiocarbon dates obtained on charcoal fragments collected along the middens' stratigraphy (Table 1). Radiocarbon date series were all stratigraphically consistent. Bayesian depth-age models were calculated using the Bacon program (Blaauw and Christen 2011) with a broad distribution of accumulation rate and a low memory strength parameter to allow for large flexibility in the accumulation rate (Fig. 3). Default values of $t . a$ and $t . b$ (3 and 4 respectively) 
parameters of the student'st-distribution were used. Based on these models, calibrated dates and their $95 \%$ confidence interval were calculated for the depth boundaries of the stratigraphic sections. Three shells (from A10, A12, and A49) were directly radiocarbon dated from a shell hinge fragment. Calibration of these dates was performed using mixed terrestrial and marine radiocarbon calibration curves (Reimer et al. 2013). We used the marine reservoir age ( $R=511 \pm 50 \mathrm{yrs})$ estimated for Senegal by Ndeye (2008), and a percentage of marine carbon calculated from the shell $\delta^{13} \mathrm{C}$ value, considering two end members of $0 \%$ for marine carbon and $-25 \%$ for terrestrial carbon ( $72 \%$ of marine carbon for A10, $64 \%$ for A12, and 92\% for A49, see Table 1).

\subsection{Shell analysis}

\section{5 modern shells and 120 archaeological shells were analyzed. Shells were embedded in} polyester resin and radially cut with a low-speed diamond saw to extract a $1 \mathrm{~mm}$ thick lamina that was then mounted on a microscope slide and polished. A sample of aragonite powder was collected by drilling a thin groove across the hinge cross section using an automated microsampler Micromill@. Each groove crossed the most part of the hinge growth, so that the aragonite sample integrates most of the shell lifetime, $\sim 5$ years in average (Fig. 4A). One fossil shell and 16 modern shells were serially microsampled in the outer shell layer with a time resolution corresponding to approximately one month following the procedure described

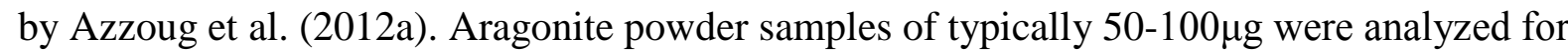
their isotopic composition $\left(\delta^{13} \mathrm{C}\right.$ and $\left.\delta^{18} \mathrm{O}\right)$ using a Thermo Finnigan Delta $\mathrm{V}$ isotope ratio mass spectrometer coupled to a Kiel IV carbonate device. Long-term reproducibility for $\delta^{13} \mathrm{C}$ and $\delta^{18} \mathrm{O}$ was better than $0.05 \%$ and $0.08 \%$ respectively based on repeated internal lab standard analyses. Isotopic analyses of aragonite samples from Tioupane and Diofandor were 
replicated 2 to 5 times. Shell isotopic ratios $\left(\delta^{13} \mathrm{C}\right.$ and $\left.\delta^{18} \mathrm{O}\right)$ were reported as relative deviation from the V-PDB international reference. Since isotopic standards for calcium carbonates are all calcitic and because aragonite and calcite have different acid fractionation factors, a correction of $-0.38 \%$ (at $70^{\circ} \mathrm{C}$ ) was applied to aragonite isotopic values following Kim et al. (2007).

\subsection{Environmental monitoring and calibration}

As a function of the region's highly seasonal rainfall regime, the salinity (and the water oxygen isotopes) of the estuary varies seasonally from brackish in the monsoon season to hypersaline in the dry season. The relationship between shell $\delta^{18} \mathrm{O}$ and local climate was determined by an in situ environmental monitoring in Toubakouta and isotopic analysis of modern shells collected live in Toubakouta and in 4 other sites from across the estuary (Fig. 1). In Toubakouta, sea surface temperature was measured hourly with an Onset Tidbit.v2 datalogger since 2011. Rainfall was measured with an Onset RG-3 rain gauge datalogger since 2011. Sea water samples were collected weekly for $\delta^{18} \mathrm{O}_{w}$ since November 2010. The oxygen isotopic composition of water samples was measured using a dual inlet Isoprime IRMS with the conventional $\mathrm{CO}_{2}-\mathrm{H}_{2} \mathrm{O}$ equilibration method (Cohn and Urey 1938). The standard error estimated from repeated standard measurement was $0.07 \%$. Water $\delta^{18} \mathrm{O}$ values were reported as relative deviations from the V-SMOW international standard. Highresolution isotopic records of modern shells from Toubakouta allowed us to study seasonal scale variability of shell isotopic ratios and their relationship with local climate (Fig. 5).

The first observation is that high resolution shell $\delta^{18} \mathrm{O}$ records from Toubakouta show a good reproducibility (Fig. 5A). Then, we calculated $\delta^{18} \mathrm{O}_{\mathrm{w}}$ from modern shell $\delta^{18} \mathrm{O}$ using the Grossman and Ku's third paleotemperature equation (Grossman and $\mathrm{Ku} 1986$ ) and the local 
mean SST annual cycle. Since calculated values faithfully reproduce measured water $\delta^{18} \mathrm{O}_{\mathrm{w}}$ (Fig. 5D), we conclude that $S$. senilis shells precipitate in isotopic equilibrium. At the seasonal scale, $\delta^{18} \mathrm{O}_{\mathrm{w}}$ accounts for $\sim 3 \%$ in aragonite $\delta^{18} \mathrm{O}$ variations while the $8^{\circ} \mathrm{C}$ range of temperature may account for $1.7 \%$ change in shell aragonite. However, because the temperature cycle is not in phase with $\delta^{18} \mathrm{O}_{\mathrm{w}}\left(\delta^{18} \mathrm{O}_{\mathrm{w}}\right.$ lags by $\sim 3$ months), it contributes positively to the shell $\delta^{18} \mathrm{O}$ range only during the rainy season which represents a temperature variation of $2-3^{\circ} \mathrm{C}$. The temperature contribution to the shell isotopic variations is thus only 0.4 to $0.6 \%$. $\delta^{18} \mathrm{O}_{\mathrm{w}}$ is the primary driver $(85 \%)$ of shell $\delta^{18} \mathrm{O}$ variations at the seasonal time scale. On longer time scales, this predominance of $\delta^{18} \mathrm{O}_{\mathrm{w}}$ influence is expected to be even larger since rainfall long-term variability is much larger than temperature variability.

The Toubakouta rainfall record (Fig. 5E) shows that the rainy seasons correspond exactly to the periods of decreasing $\delta^{18} \mathrm{O}_{\mathrm{w}}$ values (reversed scale), while dry seasons correspond to periods of increasing $\delta^{18} \mathrm{O}_{\mathrm{w}}$ values, a pattern that is also clear in shell $\delta^{18} \mathrm{O}$ records. The estuary water isotopic values, closely linked to salinity (Fig. 6), become lower than sea water values in the rainy season and higher than the sea water values in the dry season (Fig 5C). The sea water $\delta^{18} \mathrm{O}_{\mathrm{w}}$ measured at the mouth of the Delta in the dry season is close to $1 \%$. This in situ calibration dataset demonstrates that shell $\delta^{18} \mathrm{O}$ faithfully reflect $\delta^{18} \mathrm{O}_{\mathrm{w}}$ which is closely linked to precipitation.

\subsection{Spatial variability across the Delta}

Since fossil shells were collected in different sites within the Saloum Delta, we studied the spatial variability of isotopic values in modern shells from across the Delta. First, modern shell $\delta^{18} \mathrm{O}$ values show no statistically significant difference between the five collection sites

(Fig. 7). This means that the variability within the fossil $\delta^{18} \mathrm{O}$ record cannot be explained by 
changes in their origin. In contrast, there is a clear negative trend for shell $\delta^{13} \mathrm{C}$ toward the continent (Fig. 7). This gradient can be explained by the mixing of two carbon sources: dissolved inorganic carbon from the ocean $(\sim 0 \%)$ and terrestrial carbon, primarily from mangrove litter ( - 25\%). Since this gradient is also observed during the dry season when the Saloum Delta is an inverse estuary, the mixing of carbon is not due to the mixing of marine $v s$ runoff water but to tidal mixing. In estuaries where DIC $\delta^{13} \mathrm{C}$ has very large variations, mollusk shell $\delta^{13} \mathrm{C}$ variability primarily reflects DIC $\delta^{13} \mathrm{C}$ (Gillikin et al. 2006). In this setting, shell $\delta^{13} \mathrm{C}$ can thus be used to estimate the ratio of terrestrial $v s$ marine carbon 1) for calibration of shell radiocarbon dates, and 2) to estimate past changes in the tidal mixing due to the estuary geomorphology. $\delta^{13} \mathrm{C}$ values of fossil shells from Diofandor and Tioupane fall on the trend defined by modern shells (Fig. 7) suggesting that despite the strong dynamicity of delta environments, the general morphology of the estuary remained similar to the current one during the studied period. $\delta^{13} \mathrm{C}$ values from Dioron Boumak shells are more positive than the prediction of the modern trend, suggesting a stronger connection with the sea, but still within the range of modern Saloum shells. The last marine transgression has been dated by Faure et al. (1980) at $1545 \pm 120{ }^{14} \mathrm{C} \mathrm{BP}$ and was approximately $0.5 \mathrm{~m}$ high. This would correspond to the very beginning of our record and could partly explain Dioron Boumak $\delta^{13} \mathrm{C}$ values, but could not account for the more negative $\delta^{18} \mathrm{O}$ values at Dioron Boumak compared to modern values. The general consistency of past $\delta^{13} \mathrm{C}$ values with the modern estuary geomorphology, and the fact mean shell $\delta^{18} \mathrm{O}$ values are constant across the estuary show that the estuary morphology cannot account for the long-term oxygen isotope variability. This result confirms geomorphological studies which suggested that the geometry of the Saloum Delta 1500 years ago was already similar to the modern conditions (Barusseau et al. 1995; Diara and Barusseau 2006). 
2.6. Accuracy of bulk isotopic analyses in Senilia senilis shells

Most shell isotopic values in this study were obtained from bulk sampling in the hinge part of the shell. Isotopic values obtained from bulk samples could potentially be biased because bivalve shell growth can stop or change because of physiological factors (age, reproduction) or environmental factors (Goodwin et al. 2003). We discuss here the causes of shell growth variations, their potential effect on bulk isotopic values, and eventually evaluate the accuracy of bulk isotopic analyses in this study. S. senilis is a euryhaline species that has been observed live in salinities ranging from 0 to $60 \mathrm{psu}$, on intertidal mudflats in coastal lagoons from Mauritania to Angola (Elouard and Rosso 1977; Debenay et al. 1994; Azzoug 2012; Lavaud et al. 2013) . S. senilis can thus support and record large salinity changes. Seasonal salinity variations in our study sites are clearly within this tolerance range. The study of growth increment thickness and periodic growth lines (sclerochronology) related to lunar tidal cycles observed in S. senilis shells (Fig. 4) allows for a detailed control of growth rate changes or stops through the shell's life (Azzoug et al. 2012a; Debenay et al. 1994; Lavaud et al. 2013). In Mauritania, shell growth rate is lower in the cool season (November-February) (Lavaud et al. 2013), while in the Saloum Delta, it is lower during the rainy season (July-September) (Azzoug et al. 2012a). The number of periodic growth lines per year observed in shells indicates that shells grow continuously throughout the year so that the full annual cycle is recorded (Azzoug et al. 2012a). In some bivalve species, mainly from mid-to high latitudes, the length of the seasonal slowdown or shutdown increases with age which produces a progressive decrease in the seasonal isotopic range and an overall systematic trend in high resolution isotopic shell records (Goodwin et al. 2003). Such a systematic trend was not observed in modern or fossil shells of S. senilis (Azzoug 2012). 
Nevertheless, growth slowdown in the rainy season may bias bulk analyses toward dry season conditions characterized by less negative $\delta^{18} \mathrm{O}$ values. We estimated the effect of bulk sampling on isotopic values by comparing bulk values with average values obtained from high-resolution isotopic records in 15 modern shells from 3 locations in the Saloum Delta. Shell high-resolution isotopic records were resampled at a constant monthly resolution to avoid biases due to variations in temporal resolution. The difference between bulk isotopic values and averaged monthly values ranged from $-0.57 \%$ to $0.83 \%$. The average difference is $0.22 \pm 0.44 \%$ o $(1 \sigma)$. A student t-test shows that the bias due to bulk sampling is not different from zero at the 0.05 significance level. This demonstrates that bulk sampling does not significantly affect the accuracy of isotopic data in this study. It does introduce noise to the signal $(\sigma \approx 0.44 \%$ ), that we interpret as primarily related to variations in the relative contribution of rainy and dry seasons in the shell life span. For serially sampled shells, we used the average of the hinge bulk value and of the high-resolution record mean.

\subsection{A composite record of shell $\delta^{18} \mathrm{O}$ centennial variability}

$$
\text { The record is composed of } 164 \text { isotopic values including } 120 \text { archaeological shell values }
$$
(Fig. 8). Except for the three shells that were directly radiocarbon dated, each of these archaeological shell values is floating in a time interval defined by the ages of the upper and lower depths of the stratigraphic section where the shell was collected (see section 2.1). Since these shells do not have an assigned depth, their age cannot be directly estimated from the age model. Only the upper and lower boundaries of stratigraphic sections can be dated using the age model. From this floating discontinuous dataset, we built a continuous record of the probability distribution of the average shell aragonite $\delta^{18} \mathrm{O}$ value. This was achieved through a Monte Carlo (MC) sampling where iterations represent random possibilities of the floating 
chronology. In every iterations, the first step is a random sampling of the age of the stratigraphic sections' limits from their respective probability density function determined by the Bayesian depth-age model (Fig. 3). Once the time boundaries of stratigraphic sections have been fixed, the second step assigns a random age for each shell within the time interval represented by its stratigraphic section. In addition to the chronology uncertainty, the uncertainty on $\delta^{18} \mathrm{O}$ values related to bulk sampling was also sampled from a normal distribution ( $\mu=0, \sigma=0.44 \%$ ). A 7 point moving average is then calculated and annually interpolated. 10000 iterations provide us with an ensemble of potential moving average curves. Moving average curves smooth out the high frequency variability and most of the data scattering related to shell sampling. This ensemble yields the probability distribution through time of the centennial scale average shell $\delta^{18} \mathrm{O}$ value, represented by the gray scale in Fig. 8 , a median value and a $95 \%$ confidence interval. The procedure was tested with running windows of 5, 7, and 10 points. The running window size slightly affects the size of the confidence interval but not the main features of our results, which shows that the method is robust to different window widths. The statistical representativeness of the dataset through time was estimated by the average number of shells per century in the MC experiment (Fig. 8B). The least robust period is the $14^{\text {th }}$ century with an average number of only 1.5 shells, while the most robust (apart from the modern sample) is the $13^{\text {th }}$ century with 12.8 shells. We have 7.1 shells per century in average (excluding the modern period). Considering that each shell integrates in average $\sim 5$ years, and assuming no significant overlap, this means that the record was built with $\sim 35$ years per century in average, which is statistically robust to estimate centennial mean conditions $(\mathrm{CI}= \pm 1.96 \cdot \sigma / \sqrt{\mathrm{N}}= \pm 0.17 \%$ ) even considering all possible uncertainty sources related to mollusk shells (Carré et al. 2012). The raw dataset, the reconstructed annual isotopic time series and the Matlab code of the MC procedure are available in the electronic supplementary materials (Online Resource 1, 2, 3). 


\section{Results}

Significant centennial variations of shell $\delta^{18} \mathrm{O}$ show values depleted relative to the present day during the whole preindustrial part of the record. The record can be divided into three broad periods that roughly correspond to the Medieval Climate Anomaly (MCA; AD 8001250), the Little Ice Age (AD 1400-1850) and the industrial period (1850-today) (Fig. 8). The MCA period shows a slight increasing trend of aridity until a maximum at $c a \cdot-1.7 \pm 0.2 \%$ in the $12^{\text {th }}$ century. The transition into the LIA is characterized by decreasing isotopic values from $\mathrm{AD} 1200$ to $\mathrm{AD} 1500$, to reach a minimum value of $c a$. $-2.6 \pm 0.3 \%$ from $c a$. $\mathrm{AD} 1500$ to $\mathrm{AD} 1800$, corresponding to the coolest period of the LIA. An abrupt increasing trend started in the late 18th century and has continued through to the present day, which has clearly the most positive isotopic values $(-1 \pm 0.15 \%)$ of the last 1600 years. The values of the modern period are significantly enriched compared to the LIA, the MCA, or the whole preindustrial period (t-test, 0.01 significance level) (Fig. 8, Fig. 9). The difference between MCA and LIA values is also statistically significant (t-test, 0.01 significance level).

The isotopic pattern in Senegal is strikingly similar to the pattern of temperature change in the northern hemisphere (Fig. 10). We thus tested the correlation of the shell isotopic record with a global temperature reconstruction (Pages2k 2013) and two north hemisphere reconstructions (Moberg et al. 2005; Mann et al. 2009). To account for the degrees of freedom of our dataset (163) and the chronology uncertainty, we calculated the Pearson correlation coefficients using the 163 raw isotopic values coupled to the temperature reconstruction values taken at the dates of the Monte Carlo chronologies, which provides an ensemble of correlation coefficients with each temperature reconstruction. The average correlation coefficients obtained with Pages2k, Moberg and Mann's reconstructions are $\mathrm{R}=0.28$ 
( $\mathrm{p}=0.019), \mathrm{R}=0.27(\mathrm{p}=0.022)$, and $\mathrm{R}=0.20(\mathrm{p}=0.092)$ respectively. The correlation between the Saloum isotopic record and temperature reconstruction is thus statistically significant at the 0.05 significance level for Pages $2 \mathrm{k}$ global reconstruction and Moberg north hemisphere reconstruction.

We compared the monthly resolved isotopic signals of a LIA shell from Diofandor and a modern shell collected live in the same location. Both shells exhibit a perfectly regular seasonal $\delta^{18} \mathrm{O}$ signal, recording 4 monsoon seasons for the modern shell and 5 monsoon seasons in the fossil shell (Fig. 11). The LIA shell $\delta^{18} \mathrm{O}$ values are significantly more negative than modern shell values by $1.18 \%$ on average (t-test, $\mathrm{p}$-value $<0.001$ ), in agreement with centennial scale variations. Rainy season conditions in the modern shell correspond to average conditions in the fossil shells. Growth slowdowns observed in shell growth lines were similar in the modern and the fossil shell. They occurred in both cases during the rainy season and were similar in length. These observations combined with the consistency of high resolution and bulk isotopic values confirm (1) that fossil shells are well preserved, (2) that growth was continuous year-round and not significantly different in fossil shells, including those that lived in the most different conditions from today. The amplitude of seasonal variations was $40 \%$ larger in the LIA shell compared to the modern shell.

\section{Discussion}

\subsection{Interpretation of the isotopic record}

Since $S$. senilis aragonite was showed to precipitates in isotopic equilibrium with the ambient water (Fig. 5), shell $\delta^{18} \mathrm{O}$ values are determined by water temperature and $\delta^{18} \mathrm{O}_{\mathrm{w}}$ only (Grossman and $\mathrm{Ku} 1986$ ). We find that temperature cannot account for the shell $\delta^{18} \mathrm{O}$ 
centennial variability, as shown by the sign and amplitude of the centennial isotopic signal: if temperature were here the primary influence, the $\sim 1.5 \%$ increase observed in aragonite $\delta^{18} \mathrm{O}$ in the past 200 years would represent a $6.5^{\circ} \mathrm{C}$ cooling, which is unrealistic and opposed to observations (Kuhnert and Mulitza 2011; Nicholson, 2013) (Fig. 10b). Hence, our signal must result from centennial changes in the estuary $\delta^{18} \mathrm{O}_{\mathrm{w}} \cdot \delta^{18} \mathrm{O}_{\mathrm{w}}$ in the Saloum Delta is determined by 1$)$ the relative contribution of sea water $\left(\delta^{18} \mathrm{O}_{\mathrm{w}} \sim 1 \%\right.$ in this area) versus monsoon rainfall water $\left(\delta^{18} \mathrm{O} \sim-4.9 \pm 0.4 \%\right.$ ), and 2$)$ evaporation (Fig. 6). We showed that the relative contribution of both end members was not significantly affected through time by changes in the sea level or in the estuary connection to the sea (see section 2.5 ). On the other hand, the strong increasing trend observed in the Saloum salinity from 1960 to 1990 shows the sensitivity of water chemistry to changes in the P-E budget (Pagès and Citeau, 1990; Savenije and Pagès, 1992; Mikhailov and Isupova, 2008). The estuary $\delta^{18} \mathrm{O}_{\mathrm{w}}$ could additionally be affected by changes in the rain water isotopic composition, which could result from a change in the moisture source or by a change in rainfall intensity (amount effect). Isotopic changes due to the rainfall amount effect would strengthen this pattern. A change in the moisture source cannot be ruled out, but we don't expect it to have a major quantitative effect since it would only affect one of both end members. Therefore, we suggest that $\delta^{18} \mathrm{O}$ variations in the Saloum water and shells reflect changes in the P-E budget, with more positive (negative) values indicating arid (humid) conditions.

We discuss now whether P-E changes observed in the past 1600 years are primarily due to changes in evaporation or in the precipitation regime. Before AD 1850, the magnitude of temperature changes in Senegal sea water (Kuhnert and Mulitza 2011) and in global reconstructions (Moberg et al. 2005; Mann et al. 2009; Pages2k 2013) seems too small $\left(<0.5^{\circ} \mathrm{C}\right)$ to induce significant changes in evaporation (Fig. 10), which suggests that the preindustrial P-E centennial variability is likely primarily related to precipitation changes. Since 
AD 1880, a warming of $\sim 1^{\circ} \mathrm{C}$ has been measured in the ocean (ERSST 3b) (Smith et al. 2008) and $\sim 1-2^{\circ} \mathrm{C}$ on the continent (Nicholson 2013) that must have induced an increased evaporation. An important indication, however, is given by the African Southwesterly Index (ASWI), reconstructed from historical wind direction measurements, which indicates a clear decreasing trend of rainfall in western Sahel since at least AD 1840 (Gallego et al. 2015). This rainfall record, in agreement with our data, suggests that the aridification trend observed in our isotopic record for the past 200 years is not only due to an increased evaporation but largely to a rainfall deficit. Finally, more intense monsoon precipitation during the LIA is indicated in the LIA shell isotopic record by $\sim 40 \%$ larger seasonal peaks compared to the modern shell (Fig. 11). During the monsoon season, calculated water isotopic values reached $\sim-2.8 \%$ o $\left(-3.1 \%\right.$ when considering $1.5^{\circ} \mathrm{C}$ lower temperature in the LIA) which corresponds to a salinity of $\sim 13$ psu (11 psu considering LIA temperature change). Such a low value close to the estuary mouth requires a strong freshwater flow that is never observed today.

In conclusion, the Saloum isotopic variations reflect hydroclimate changes primarily due to changes in local precipitation, which come almost entirely from the West African Monsoon system. This means that (1) the AD 1500-1800 period in LIA was the most humid period in the past 1600 years, (2) an abrupt aridification occurred in the past 200 years, (3) in the context of the past 1600 years, drought conditions in western Sahel have emerged in the 20th century from the range of natural climate variability.

\subsection{The regional context}

$$
\text { Records of hydroclimate in the past } 1600 \text { years are extremely scarce in the Sahel region. }
$$
Some documentary and archaeological evidence indicate moister conditions in the medieval period. In Mauritania, the Ghana empire thrived in the 11th century suggesting a more 
prosperous agriculture (El-Bekri 1859). Awdaghust was an active trade city in the 8th to 14th century in what is today an extreme desert (Robert 1970). In the 16th century, Portuguese explorer Fernandes reports that farmers did two crop yields per year in the Saloum region while rainfall today only allows for one (Fernandes et al. 1951; Daveau 1969). Documentary sources were used to reconstruct rainfall variability in Africa since AD 1800 (Nicholson et al. 2012). These sources indicate a very strong drought in the Sahel from AD 1800 to AD 1850, also supported by evidence of a drop in the Lake Chad level approximately at this time (Maley 1981). Considering the response time of the Saloum mean salinity, the drought reported in historical documents is consistent with the onset of the abrupt isotopic trend recorded by shells in the Senegal $c a$. AD 1800. West of Lake Chad, dust and ostracod $\delta^{18} \mathrm{O}$ records were obtained from two oasis (Street-Perrott et al., 2000; Cockerton et al., 2014). While dust flux increased through the past 2000 years possibly in relation to the changing volume of Lake Chad and to human activities, ostracod $\delta^{18} \mathrm{O}$ show slightly more negative values in the LIA than in the MCA, suggesting more humid conditions in the LIA in agreement with our record. No recent increase of $\delta^{18} \mathrm{O}$ values was observed in these sites, either because of different local conditions or because of a truncation of the core top.

A continuous record of WAM variability was provided by calcite $\delta^{18} \mathrm{O}$ measured in Lake Bosumtwi, Ghana (Shanahan et al. 2009). Interestingly, the Saloum hydrological changes are very different from those recorded at Lake Bosumtwi (Fig. 10), which is located in the convective zone of the monsoon. On the other hand, the Saloum isotopic record shows similarity over the past 700 years with the first EOF of eastern Africa Lake records (Tierney et al. 2013) and with a record of past precipitation located at the same latitude in the Gulf of Aden (Tierney et al. 2015) (Fig. 10). These results suggest that the spatial coherence of rainfall across the Sahel, as well as the weak correlation between the Sahel and the Gulf of 
423 Guinea observed in the instrumental data at the decadal scale (Fig. 1) applies also at the 424 centennial time scale.

4.3. Sahel rainfall and global climate change

427

Explanations of millennial to centennial scale rainfall variability in the tropics have been often related to latitudinal shifts of the mean position of the ITCZ in response to interhemispheric temperature contrasts (Street-Perrott and Perrot, 1990; Mulitza and Rühlemann, 2000; Haug et al. 2001; Yancheva et al., 2007). Following this model, and according to paleoclimate records from the Pacific (Sachs et al. 2009), South America (Haug et al. 2001, Bird et al., 2011), Asia (Yan et al. 2015), and East Africa (Brown and Johnson 2005), the LIA is characterized by a relatively southern position of the July ITCZ (Fig. 10), which is in apparent contradiction with increased humidity over the Sahel during this period. The centennial variability of conditions in the Sahel must therefore be governed by processes more complex than the simple shift of the rain belt driven by the position of the July ITCZ.

Sea-surface temperature and the Atlantic multidecadal oscillation have been identified in the instrumental record as one of the main drivers of Sahel rainfall (Folland et al. 1986; Giannini et al. 2003; Zhang and Delworth 2006; Mohino et al. 2011). During positive AMO phases, increased summer precipitation is observed in the Sahel in response to a strengthening of the Sahara heat convection and increased moisture flux from the Mediterranean Sea (Martin and Thorncroft 2014). However, past temperature reconstructions suggest that the LIA period corresponds to a negative AMO-like phase (Mann et al. 2009) which, if the same type of mechanism can be invoked at a longer time-scale, would therefore tend to induce dry conditions in the Sahel, in opposition with our observations. Our multicentennial perspective shows thus that western Sahel hydroclimate centennial variability responds to remote forcings 
through processes that are different from those identified at multidecadal timescales (AMO) or millennial time scales (ITCZ shifts).

The most prominent characteristics of the Saloum hydroclimate record is the significant correlation with global or hemispheric temperature reconstructions, while no correlation is observed with local SSTs (Fig. 10), suggesting that low frequency variability of Sahel rainfall primarily depends on changes in the global atmospheric circulation. Although determining the mechanisms responsible for the observed negative relationship between western Sahel rainfall and global temperature is beyond the scope of this study, our results bring new constraints to understand the processes that affect Sahel rainfall in the context of the on-going long-term global warming trend.

First, the facts that (1) over the past 200 years, the strong aridification in the Western Sahel coincides with rapid global warming, and (2) that drought conditions in western Sahel are today beyond the range of the pre-industrial climatic variability of the past 1600 years, point to an anthropogenic forcing of the Sahel drying trend. The last 200 years have also seen the development and expansion of commercial agriculture in the Sahel, corresponding to an increase of Saharan aeolian dust flux (Fig. 10) as a result of an increased erosion due to increased agricultural land use (Mulitza et al. 2010). This human-induced change in vegetation cover is likely to have contributed to the decrease in rainfall of the past 200 years through the positive local vegetation-precipitation feedback. This local effect was probably combined with the global effect of anthropogenic warming that modified the tropical atmospheric circulation.

Second, the negative relationship between western Sahel rainfall and global temperature revealed by our reconstruction is in agreement with model and instrumental data analyses that showed a decreasing trend of rainfall in the margin of the convective regions (Allan and Soden 2007) and a narrowing of the ITCZ as a result of global warming (Lau and Kim, 2015; 
Byrne and Schneider 2016; Wodzicki and Rapp 2016; Su et al., 2017). The result is an enhancement of the Precipitation-Evaporation pattern (Held and Soden, 2006). This trend has been attributed to the "upped-ante mechanism" (Neelin et al. 2003), which describes changes in horizontal moisture advection, and to a strengthening of the meridional gradient of moist static energy with warming of the troposphere (Byrne and Schneider 2016). Our reconstruction supports climate models predicting increasing drought in the Sahel with future global warming (Held et al. 2005), although a majority of climate models tend now to predict wetter future climate (Biasutti 2013). It also suggest that the rainfall "recovery" of the past 15 years in the Sahel is likely related to short-term multidecadal internal climate variability. In the context of the past 1600 years, the modern conditions in western Sahel should be considered as an extreme drought likely caused by human activities. Although the nature of external forcings in the 21 st century is different from the pre-industrial period, the long-term relationship evidenced here underlines the risk of a major drought crisis in the $21^{\text {st }}$ century. Further paleoclimate reconstructions combined with paleoclimate modeling experiments are required to confirm and understand centennial scale Sahel hydroclimate variability and constrain greenhouse climate predictions in this region.

\section{References}

Allan RP, Soden BJCL (2007) Large discrepancy between observed and simulated precipitation trends in the ascending and descending branches of the tropical circulation. Geophysical Research Letters 34 http://dx.doi.org/10.1029/2007GL031460

Azzoug M (2012) Reconstitution des variations multidecennales et saisonnières de la mousson ouest-Africaine au cours des deux derniers millénaires à partir de l'étude 
sclérochronologique des amas coquilliers fossiles dans le delta du Saloum, Sénégal. Unpublished PhD, Université Montpellier 2

Azzoug M, Carré M, Chase BM, Deme A, Lazar A, Lazareth CE, Schauer AJ, MandengYogo M, Simier M, Thierno-Gaye A, de Morais LT (2012) Positive precipitationevaporation budget from AD 460 to 1090 in the Saloum Delta (Senegal) indicated by mollusk oxygen isotopes. Global and Planetary Change 98-99:54-62.

Azzoug M, Carré M, Schauer AJ (2012a) Reconstructing the duration of the West African Monsoon season from growth patterns and isotopic signals of shells of Anadara senilis (Saloum Delta, Senegal). Palaeogeography, Palaeoclimatology, Palaeoecology 346$347: 145-152$.

Barusseau JP, Bâ M, Descamps C, Salif Diop EH, Giresse P, Saos JL (1995) Coastal Evolution in Senegal and Mauritania at $10^{3}, 10^{2}$ and $10^{1}$-year scales: Natural and human records. Quaternary International 29/30:61-73.

Biasutti M (2013) Forced Sahel rainfall trends in the CMIP5 archive. Journal of Geophysical Research: Atmospheres 118:1613-1623. http://dx.doi.org/10.1002/jgrd.50206

Bird BW, Abbott MB, Vuille M, Rodbell DT, Stansell ND, Rosenmeier MF (2011) A 2,300year-long annually resolved record of the South American summer monsoon from the Peruvian Andes. Proc. Natl Acad. Sci. USA 108:8583-8588.

Blaauw M, Christen JA (2011) Flexible paleoclimate age-depth models using an autoregressive gamma process. Bayesian Analysis 6:457-474.

Brown ET, Johnson TC (2005) Coherence between tropical East African and South American records of the Little Ice Age. Geochemistry, Geophysics, Geosystems 6:Q12005. http://dx.doi.org/10.1029/2005GC000959 
Byrne MP, Schneider T (2016) Narrowing of the ITCZ in a warming climate: physical mechanisms. Geophysical Research Letters:2016GL070396. http://dx.doi.org/10.1002/2016GL070396

Carré M, Sachs JP, Wallace JM, Favier C (2012) Exploring errors in paleoclimate proxy reconstructions using Monte Carlo simulations: paleotemperature from mollusk and coral geochemistry. Climate of the Past 8:433-450.

Christensen JH, Kanikicharla KK, Marshall G, Turner J (2013) Climate phenomena and their relevance for future regional climate change. In: Climate Change 2013, The physical science basis. Cambridge University Press, p 1217-1308

Cockerton HE, Holmes JA, Street-Perrott FA, Ficken KJ (2014) Holocene dust records from the West African Sahel and their implications for changes in climate and land surface conditions. Journal of Geophysical Research: Atmospheres 119:8684-8694. doi: 10.1002/2013JD021283

Cohn M, Urey HC (1938) Oxygen exchange reactions of organic compounds with water. Journal of the American Chemical Society 60:679-687.

Daveau S (1969) La découverte du climat au cours des navigations portugaises. Bull. Inst. Fr. Afr. Noire, série B 31:953-988.

Debenay JP, Leung Tack D, Ba M, Sy I (1994) Environmental conditions, growth and production of Anadara senilis (Linnaeus, 1758) in a Senegal lagoon. Journal of Molluscan Studies 60:113-121.

Diara M, Barusseau JP (2006) Late Holocene evolution of the Salum-Gambia double delta (Senegal). Geo-Eco-Marina 12:17-28.

El-Bekri, translated by De Slane MG (1859) Description de l'Afrique Septentrionale, Vol. Imprimerie Impériale, Paris 
Elouard P, Rosso J-C (1977) Biogéographie et habitat des mollusques actuels laguno-marins du delta du Saloum (Sénégal). Geobios 10:275-296, IN271-IN273.

Faure H, Fontes JC, Hebrard L, Monteillet J, Pirazzoli PA (1980) Geoidal Change and ShoreLevel Tilt Along Holocene Estuaries: Senegal River Area, West Africa. Science 210:421-423.

Fernandes V, Monod T, Mauny R (1951) Description de la côte occidentale d'Afrique:(Sénégal du Cap de Monte, Archipels), Centro de Estudos da Guiné Portuguesa

Folland CK, Palmer TN, Parker DE (1986) Sahel rainfall and worldwide sea temperatures, 1901-85. Nature 320:602-607. http://dx.doi.org/10.1038/320602a0

Gallego D, Ordóñez P, Ribera P, Peña-Ortiz C, García-Herrera R (2015) An instrumental index of the West African Monsoon back to the nineteenth century. Q. J. R. Meteorol. Soc. 141:3166-3176. http://dx.doi.org/10.1002/qj.2601

Giannini A, Saravanan R, Chang P (2003) Oceanic forcing of Sahel rainfall on interannual to interdecadal time scales. Science 302:1027-1030.

Gillikin DP, Lorrain A, Bouillon S, Willenz P, Dehairs F (2006) Stable carbon isotopic composition of Mytilus edulis shells: relation to metabolism, salinity, d13CDIC and phytoplankton. Organic Geochemistry 37:1371-1382.

Goodwin DH, Schöne BR, Dettman DL (2003) Resolution and fidelity of oxygen isotopes as paleotemperature proxies in bivalve mollusk shells: Models and observations. Palaios 18:110-125.

Grossman EL, Ku, Teh-Lung (1986) Oxygen and carbon fractionation in biogenic aragonite: temperature effect. Chemical Geology 59:59-74. 
Hardy K, Camara A, Piqué R, Dioh E, Guèye M, Diadhiou HD, Faye M, Carré M (2016) Shellfishing and shell midden construction in the Saloum Delta, Senegal. Journal of Anthropological Archaeology 41:19-32.

Haug GH, Hughen KA, Sigman DM, Peterson LC, Röhl U (2001) Southward migration of the intertropical convergence zone through the Holocene. Science 293:1304-1308.

Held IM, Delworth TL, Lu J, Findell KL, Knutson TR (2005) Simulation of Sahel drought in the 20th and 21st centuries. Proc. Natl Acad. Sci. USA 102:17891-17896.

Held IM, Soden BJ (2006) Robust Responses of the Hydrological Cycle to Global Warming. Journal of Climate 19:5686-5699.

Kim S-T, Mucci A, Taylor BE (2007) Phosphoric acid fractionation factors for calcite and aragonite between 25 and $75^{\circ} \mathrm{C}$ : Revisited. Chemical Geology 246:135-146.

Kuhnert H, Mulitza S (2011) Multidecadal variability and late medieval cooling of nearcoastal sea surface temperatures in the eastern tropical North Atlantic. Paleoceanography 26:PA4224. http://dx.doi.org/10.1029/2011PA002130

Lau WKM, Kim K-M (2015) Robust Hadley Circulation changes and increasing global dryness due to $\mathrm{CO} 2$ warming from CMIP5 model projections. Proc. Natl Acad. Sci. USA 112:3630-3635. doi:10.1073/pnas.1418682112

Lavaud R, Thébault J, Lorrain A, van der Geest M, Chauvaud L (2013) Senilia senilis (Linnaeus, 1758), a biogenic archive of environmental conditions on the Banc d'Arguin (Mauritania). Journal of Sea Research 76:61-72.

Maley J (1981) Etudes palynologiques dans le bassin du Tchad et paléoclimatologie de l'Afrique nord-tropicale de 30000 ans à l'époque actuelle. Travaux et documents de l'ORSTOM:pp. 586. 
Mann ME, Zhang Z, Rutherford S, Bradley RS, Hughes MK, Shindell DT, Ammann C, Faluvegi G, Ni F (2009) Global signatures and dynamical origins of the Little Ice Age and Medieval Climate Anomaly. Science 236:1256-1260.

Martin ER, Thorncroft CD (2014) The impact of the AMO on the West African monsoon annual cycle. Quarterly Journal of the Royal Meteorological Society 140:31-46. http://dx.doi.org/10.1002/qj.2107

Mikhailov VN, Isupova MV (2008) Hypersalinization of river estuaries in West Africa. Water Resources 35:367-385.

Moberg A, Sonechkin DM, Holmgren K, Datsenko NM, Karlén W (2005) Highly variable northern hemisphere temperatures reconstructed from low- and high-resolution proxy data. Nature 433:613-617.

Mohino E, Janicot S, Bader J (2011) Sahel rainfall and decadal to multi-decadal sea surface temperature variability. Climate Dynamics 37:419-440. doi: 10.1007/s00382-010$0867-2$

Mulitza S, Rühlemann C (2000) African Monsoonal Precipitation Modulated by Interhemispheric Temperature Gradients. Quaternary Research 53:270-274. doi:10.1006/qres.1999.2110

Mulitza S, Heslop D, Pittauerova D, Fischer HW, Meyer I, Stuut J-B, Zabel M, Mollenhauer G, Collins JA, Kuhnert H, Schulz M (2010) Increase in African dust flux at the onset of commercial agriculture in the Sahel region. Nature 466:226-228. doi:10.1038/nature09213

Nash DJ, De Cort G, Chase BM, Verschuren D, Nicholson SE, Shanahan TM, Asrat A, Lézine A-M, Grab SW (2016) African hydroclimatic variability during the last 2000 years. Quaternary Science Reviews 154:1-22. 
Ndeye M (2008) Marine Reservoir Ages in Northern Senegal and Mauritania Coastal Waters. Radiocarbon 50:281-288. doi:10.1017/S0033822200033580

Neelin JD, Chou C, Su H (2003) Tropical drought regions in global warming and El Niño teleconnections. Geophysical Research Letters 30:2275. doi:10.1029/2003GL018625

Nicholson SE (2014) Spatial teleconnections in African rainfall: A comparison of 19th and 20th century patterns. The Holocene 24:1840-1848.

Nicholson SE, Dezfuli AK, Klotter D (2012) A Two-Century Precipitation Dataset for the Continent of Africa. Bull. Amer. Meteor. Soc. 93:1219-1231.

Nicholson SE, Nash DJ, Chase BM, Grab SW, Shanahan TM, Verschuren D, Asrat A, Lézine A-M, Umer M (2013) Temperature variability over Africa during the last 2000 years. The Holocene 23:1085-1094.

Pagès J, Citeau J (1990) Rainfall and salinity of a Sahelian estuary between 1927 and 1987. Journal of Hydrology 113:325-341.

PAGES-2k (2013) Continental-scale temperature variability during the past two millennia. Nature Geosci 6:339-346. doi:10.1038/ngeo1797

Pendergrass A, National Center for Atmospheric research Staff (2016) The Climate Data Guide: GPCP (Daily): Global Precipitation Climatology Project. https://climatedataguide.ucar.edu/climate-data/gpcp-daily-global-precipitationclimatology-project

Reimer PJ, Bard E, Bayliss A, Beck JW, Blackwell PG, Bronk Ramsey C, Buck CE, Cheng H, Edwards RL, Friedrich M, Grootes PM, Guilderson TP, Haflidason H, Hajdas I, Hatté C, Heaton TJ, Hoffmann DL, Hogg AG, Hughen KA, Kaiser KF, Kromer B, Manning SW, Niu M, Reimer RW, Richards DA, Scott EM, Southon JR, Staff RA, Turney CSM, van der Plicht J (2013) IntCal13 and Marine13 Radiocarbon Age Calibration Curves 0-50,000 Years cal BP. Radiocarbon 55:1869-1887. 
Robert DS (1970) Les Fouilles de Tegdaoust. The Journal of African History 11:471-493.

Sachs JP, Sachse D, Smittenberg RH, Zhang Z, Battisti DS, Golubic S (2009) Southward movement of the Pacific intertropical convergence zone A.D. 1400-1850. Nature Geoscience 2:519-525.

Savenije HHG, Pagès J (1992) Hypersalinity: a dramatic change in the hydrology of Sahelian estuaries. Journal of Hydrology 135:157-174.

Shanahan TM, Overpeck JT, Anchukaitis KJ, Beck JW, Cole JE, Dettman DL, Peck JA, Scholz CA, King JW (2009) Atlantic Forcing of Persistent Drought in West Africa. Science 324:377-380.

Smith TM, Reynolds RW, Peterson TC, Lawrimore J (2008) Improvements to NOAA's Historical Merged Land-Ocean Surface Temperature Analysis (1880-2006). Journal of Climate 21:2283-2296. http://dx.doi.org/10.1175/2007JCLI2100.1

Street-Perrott FA, Perrott RA (1990) Abrupt climate fluctuations in the tropics: the influence of Atlantic Ocean circulation. Nature 343:607.

Street-Perrott FA, Holmes JA, Waller MP, Allen MJ, Barber NGH, Fothergill PA, Harkness DD, Ivanovich M, Kroon D, Perrott RA (2000) Drought and dust deposition in the West African Sahel: a 5500-year record from Kajemarum Oasis, northeastern Nigeria. The Holocene 10:293-302. 10.1191/095968300678141274

Su H, Jiang JH, Neelin JD, Shen TJ, Zhai C, Yue Q, Wang Z, Huang L, Choi Y-S, Stephens GL, Yung YL (2017) Tightening of tropical ascent and high clouds key to precipitation change in a warmer climate. Nature Communications 8:15771. doi:10.1038/ncomms 15771

Thilmans G, Descamps C (1982) Amas et tumulus coquilliers du delta du Saloum. In: Recherches scientifiques dans les parcs nationaux du Sénégal, Vol 92. Mémoires de l'Institut Fondamental d'Afrique Noire, Dakar, p 31-50 
Tierney JE, Smerdon JE, Anchukaitis KJ, Seager R (2013) Multidecadal variability in East African hydroclimate controlled by the Indian Ocean. Nature 493:389-392. http://dx.doi.org/10.1038/nature11785

Tierney JE, Ummenhofer CC, deMenocal PB (2015) Past and future rainfall in the Horn of Africa. Science Advances 1. doi: 10.1126/sciadv.1500682

Wade M, Mignot J, Lazar A, Gaye AT, Carré M (2015) On the spatial coherence of rainfall over the Saloum delta (Senegal) from seasonal to decadal time scales. Frontiers in Earth Science, Atmospheric Science 3:30. doi:10.3389/feart.2015.00030

Wodzicki KR, Rapp ADCJ (2016) Long-term characterization of the Pacific ITCZ using TRMM, GPCP, and ERA-Interim. Journal of Geophysical Research: Atmospheres 121:3153-3170. http://dx.doi.org/10.1002/2015JD024458

Yan H, Wei W, Soon W, An Z, Zhou W, Liu Z, Wang Y, Carter RM (2015) Dynamics of the intertropical convergence zone over the western Pacific during the Little Ice Age. Nature Geosci 8:315-320. http://dx.doi.org/10.1038/ngeo2375

Yancheva G, Nowaczyk NR, Mingram J, Dulski P, Schettler G, Negendank JFW, Liu J, Sigman DM, Peterson LC, Haug GH (2007) Influence of the intertropical convergence zone on the East Asian monsoon. Nature 445:74.

Zhang R, Delworth TLCL (2006) Impact of Atlantic multidecadal oscillations on India/Sahel rainfall and Atlantic hurricanes. Geophysical Research Letters 33. http://dx.doi.org/10.1029/2006GL026267

\section{Acknowledgements:}

The authors are thankful to César Tendeng, Ansu Mane, Iba Ndiaye, and Bernard Bassène for their assistance with fieldwork. We are thankful to Cyr Descamps for sharing his knowledge on archaeological shell middens. We thank the Institut de Recherche pour le Développement 
689 (IRD) in Senegal for the logistical support during field trips. We thank Andrew Schauer and

690 Marie Balasse for their support with isotopic analyses, Sharon Nicholson for her valuable 691 comments on the manuscript, and two anonymous reviewers. This research was funded by the 692 University of Montpellier, the French CNRS-Institut National des Sciences de l'Univers 693 through the LEFE program, and the ANR-Belmont Forum PACMEDY project (ANR- 15694 JCLI-0003-01). 


\section{FIGURE CAPTIONS}

696

697

698

699

700

701

702

703

704

705

706

707

708

709

710

711

712

713

714

715

716

717

718

719

Fig. 1. (Left) Regional representativeness of summer precipitation in the Saloum study site. Linear regression (color shades) of summer rainfall (JAS) decadal variability in the Saloum Delta (green circle) with summer rainfall in the rest of the domain, using GPCP data (Pendergrass et al. 2016). Mean summer (JAS) rainfall is shown by black contours ( $\mathrm{mm} / \mathrm{d})$. Yellow squares indicate the location, from west to east, of core GeoB9501 (Mulitza et al. 2010), Lake Bosumtwi (Shanahan et al. 2009), and core P178-15 (Tierney et al. 2015). (Right) Map of the Saloum mangrove Delta showing the location of water and modern shell sampling sites (orange circles) and fossil (blue circles) shell sampling.

Fig. 2. The Dioron Boumak shell midden. The shell midden is about $11 \mathrm{~m}$ high, $300 \mathrm{~m}$ long and topped by a baobab forest (left). It was accumulated by ancient mollusk shell gatherers during at least 600 years, and is one of the largest and best preserved archaeological shell middens of the Saloum Delta. The beach in the front is exclusively composed of S.senilis shells from the tidal erosion of the shell accumulation. (Center) Dioron Boumak stratigraphic profile sampled for charcoal fragments and fossil shells. (Right) Close up view of the shell midden showing the extreme density of the shell accumulation.

Fig. 3. Bayesian age-depth models of Dioron Boumak, Tioupane and Diofandor shell middens. Models were calculated from charcoal radiocarbon dates using the Bacon $\mathrm{R}$ software (34). Parameter values used for Bacon are indicated for each site. Two calendar dates were assigned for Diofandor (gray): $1982 \pm 3$ for the top, which corresponds to the site abandonment estimated by local witnesses, and $1957 \pm 1$ at $20 \mathrm{~cm}$. This latter date is the only possible calibrated date for this radiocarbon measurement (Table S1), after excluding the 1997-2002 interval which is inconsistent with the site abandonment date. The depth of the 
stratigraphic layers and the number of shells analyzed are indicated along the vertical axis.

For Dioron Boumak, two columns are shown corresponding to two field campaigns in 2010 (left) and 2011 (right) (Azzoug et al. 2012b).

Fig. 4. Senilia senilis sclerochronology. A: polished cross section of a fossil shell from the Saloum Delta. Dark bands can be seen in the outer layer and in the hinge (two of them are indicated by black arrows), that correspond to monsoon season growth. The lifespan of the shell can thus be estimated at about 8 years from the number of annual bands. Isotopic values presented in this study were obtained from the analysis of aragonite powder collected in the hinge along a transect that integrates most of the mollusk life. The sampling groove is here indicated by the white arrow. B: Microscope view of tidal growth lines. Clusters of darker and thicker tidal lines can be observed during spring tides every half lunar month (6). C: Scanning electronic microscope image of a perfectly preserved aragonite cross lamellar structure observed in a fossil shell hinge.

Fig. 5. Environmental monitoring and isotopic calibration in Toubakouta. (A) High resolution profiles of aragonite $\delta^{18} \mathrm{O}$ (reversed scale) measured along five modern shells of S. senilis collected live in Toubakouta (three in 2011 and two in 2013). The chronology was determined using tidal fortnightly growth lines and assigning minimum values to the average date of minimum water $\delta^{18} \mathrm{O}_{\mathrm{w}}$ (B) Daily sea surface temperature (SST) measured in Toubakouta (thin red line), and average monthly SST annual cycle (thick red line). (C) Weekly estuary water $\delta^{18} \mathrm{O}_{\mathrm{w}}$ measured in Toubakouta from 2010 to 2015. Samples of early 2013 were lost. (D) Water $\delta^{18} \mathrm{O}_{\mathrm{w}}$ calculated from shell aragonite $\delta^{18} \mathrm{O}$ (individual shells in grey, averaged shell profile in green) using Grossman and Ku third equation (Grossman and $\mathrm{Ku} 1986$ ) and the mean annual cycle of SST. Calculated $\delta^{18} \mathrm{O}_{\mathrm{w}}$ is compared with measured monthly $\delta^{18} \mathrm{O}_{\mathrm{w}}$ 
(black dotted line). (E) Monthly rainfall ( $\mathrm{mm}$ ) measured in Toubakouta. Light blue vertical bands indicate the rainy seasons.

Fig. 6. Relationship between water isotopic ratio $\left(\delta^{18} \mathrm{O}_{\mathrm{w}}\right)$ and salinity in the Saloum estuary. Water samples were collected across the estuary from Dionewar to Bombugar Malik (Fig. 1) at different seasons between 2011 and 2016. The least square linear regression is shown as well as the determination coefficient $\mathrm{R}^{2}$. Sea water ( $\left.\sim 35 \mathrm{psu}\right)$ corresponds to an isotopic ratio of $\sim 1 \%$. Higher values are observed in the dry season and indicate evaporated sea water, while lower values correspond to a mix between sea water and rain water.

Fig. 7. Gradients of shell isotopic values across the Saloum Delta. Modern shell $\delta^{18} \mathrm{O}$ (blue triangles) and $\delta^{13} \mathrm{C}$ values (red diamonds) from the 5 collection sites versus their distance to the open ocean. The black curve shows the decreasing trend of $\delta^{13} \mathrm{C}$ from the sea towards the land, as a result of the increasing contribution of mangrove carbon. Fossil shell $\delta^{13} \mathrm{C}$ (open red squares) versus the distance to the open ocean. Distances were estimated from satellite pictures.

Fig. 8. Variability of shell $\delta^{18} \mathrm{O}$ values in the past 1600 years in the Saloum Delta. (a) Isotopic values of individual shells (diamonds) are represented with $2 \sigma$ analytical error. Modern shells (black) were collected live in 5 locations across the estuary between 2011 and 2014. Fossil shells from the stratified shell middens of Diofandor (red), Tioupane (green), Dioron Boumak (blue) were dated using Bayesian age-depth models (Fig. 3). Fossil shells from sites A10, A12, and A49 (pink) were directly ${ }^{14} \mathrm{C}$ dated (Table 1). Average $\delta^{18} \mathrm{O}$ values for successive stratigraphic levels are indicated by horizontal bars. The length of thick bars indicates the most likely occupation period, and the thinner bars the $2 \sigma$ intervals. Gray scale shading 
represents the probability distribution of the shell $\delta^{18} \mathrm{O}$ moving average considering chronological uncertainty. The thick black lines represent the median probability and the dashed lines the $95 \%$ confidence interval. (b) Histogram of the average number of shells per century in the Monte Carlo sampling analysis. The average timespan integrated by a shell value is approximately 5 years. (c) Box plots of isotopic values for modern shells, and fossil shells of the MCA and LIA periods. MCA and LIA are here defined by the AD 800-1250 and AD 1450-1850 periods respectively. Box plots represent the full range of values (whiskers) excluding statistical outliers, the 25th and 75th percentiles (box edges), the median (central mark), and the confidence interval (95\% confidence level) of the median (box notch).

Fig. 9. Distributions of shell $\delta^{18} \mathrm{O}$ values per time period. Modern $=$ all modern values from live-collected shells $(\mathrm{N}=44)$ (black). $\mathrm{PI}=$ all values with median date prior to A.D. 1850 $(\mathrm{N}=109)$ (green). LIA= all values with median dates between 1450 and $1850(\mathrm{~N}=20)(\mathrm{red})$. $\mathrm{MCA}=$ all values with median dates between 800 and $1250(\mathrm{~N}=36)$ (blue). For each shell sample, isotopic values are plotted as triangles at the bottom, and the corresponding normal Kernel probability density curves are plotted $(\mathrm{n}=50$, bandwidth $=0.2)$. Mean values and the 95\% confidence intervals of the estimated mean values are represented by dashed lines and shaded areas.

Fig. 10. Comparison of the Saloum hydroclimate record with regional and global climate records. The time scale is in calendar years AD. (a) Temperature variability: northern Hemisphere temperature reconstructed by Mann et al. (2009) and smoothed with a 30-yr triangular filter (orange curve and shading), low frequency northern hemisphere temperature variability calculated by Moberg et al. (2005) (red curve and shading), global temperature anomaly (SD unit) as the area-weighted average of continent scale reconstructions by Pages- 
2k consortium (2013) (pink). Vertical red and blue shading was calculated from the temperature anomaly in Moberg et al.'s (2005) record. MCA and LIA periods are indicated above. (b) Records from marine sediment core GeoB9501: SST calculated from foraminifera $\mathrm{Mg} / \mathrm{Ca}$ (Kuhnert and Mulitza 2011) (green), and Aeolian dust flux (Mulitza et al. 2010) (brown). (c) African Southwesterly Index (ASWI) of JAS, from 1840 to 2013, with 30-yr LOESS smoothed curve (Gallego et al. 2015). (d) Shell $\delta^{18} \mathrm{O}$ density of probability (gray shading), median probability (black line) and confidence interval (dashed lines) in the Saloum estuary as an indicator of the precipitation-evaporation budget in the Western Sahel (this study). (e) Leaf wax hydrogen isotopic ratios $\left(\delta \mathrm{D}_{\text {wax }}\right)$ in the marine sediment core P178-15 from the Gulf of Aden (Tierney et al. 2015). The error bar is the \pm 1 sigma analytical precision. (f) Calcite $\delta^{18} \mathrm{O}$ in Lake Bosumtwi, Ghana, and 30-yr triangular filter smooth (Shanahan et al. 2009). (g) Ti content in ODP1002 sediment core indicating continental freshwater runoff into the Cariaco Basin, off Venezuela (Haug et al. 2001), and 10-point moving average curve (dark blue). (h) Calcite $\delta^{18} \mathrm{O}$ in Lake Pomacocha, Central Peruvian Andes (Bird et al. 2011), and 30-yr moving average (purple).

Fig. 11. Monthly resolved $\delta^{18} \mathrm{O}$ records of a modern and a fossil shell from Diofandor (Fig. 1). Average values are indicated by gray lines. Negative values reflect lower salinity. Time axes represent the shell ontogenic age. 

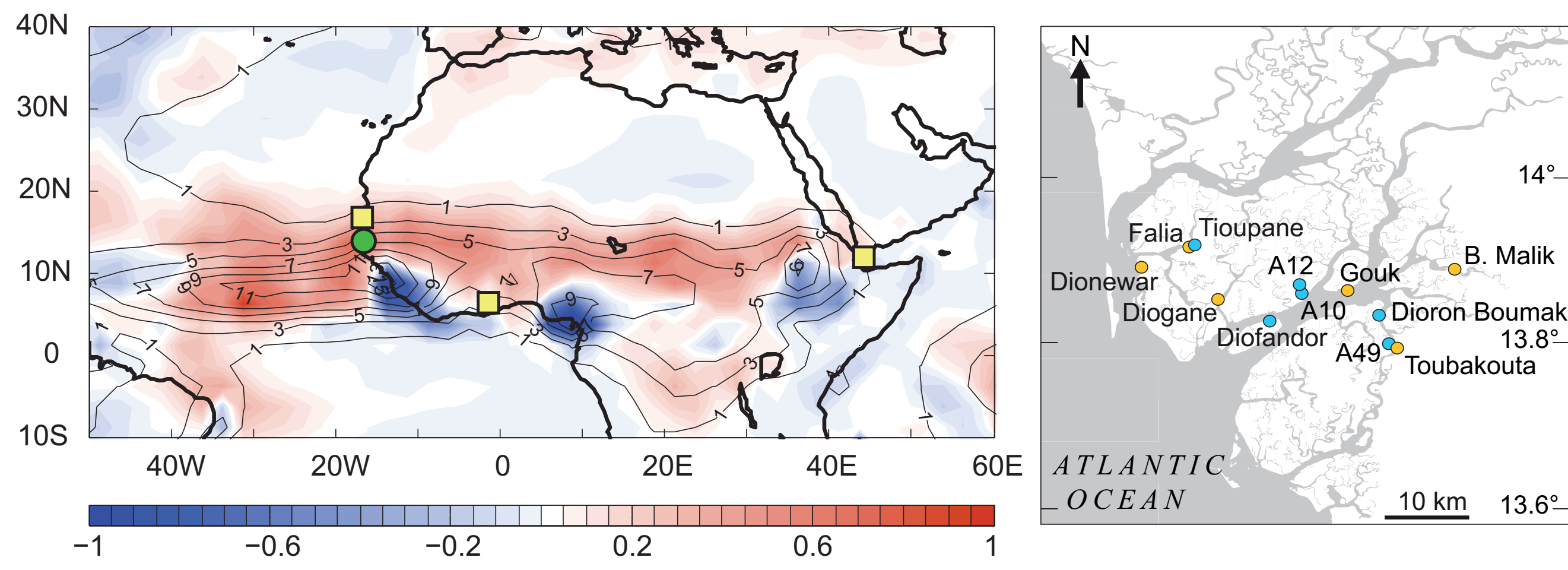


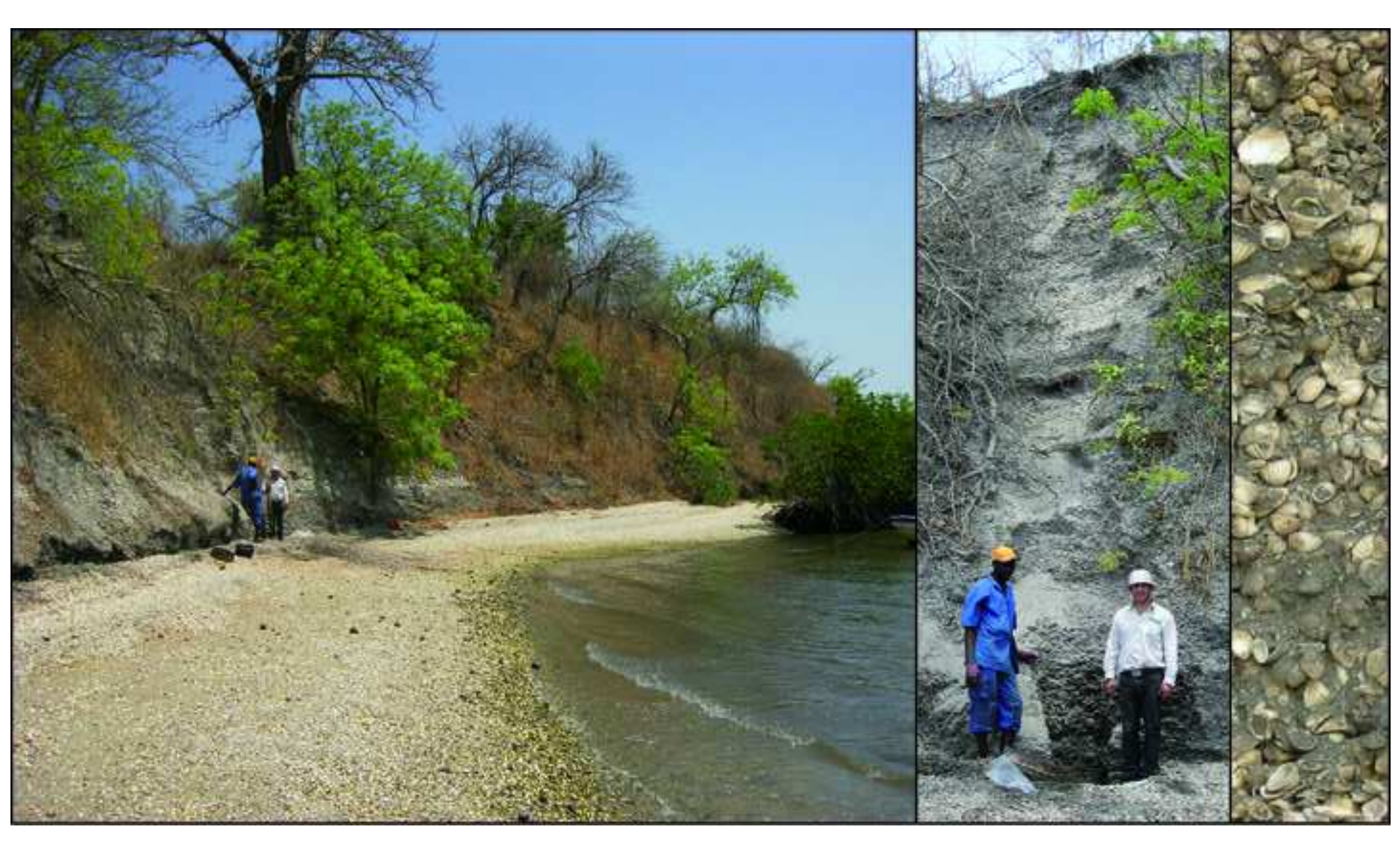



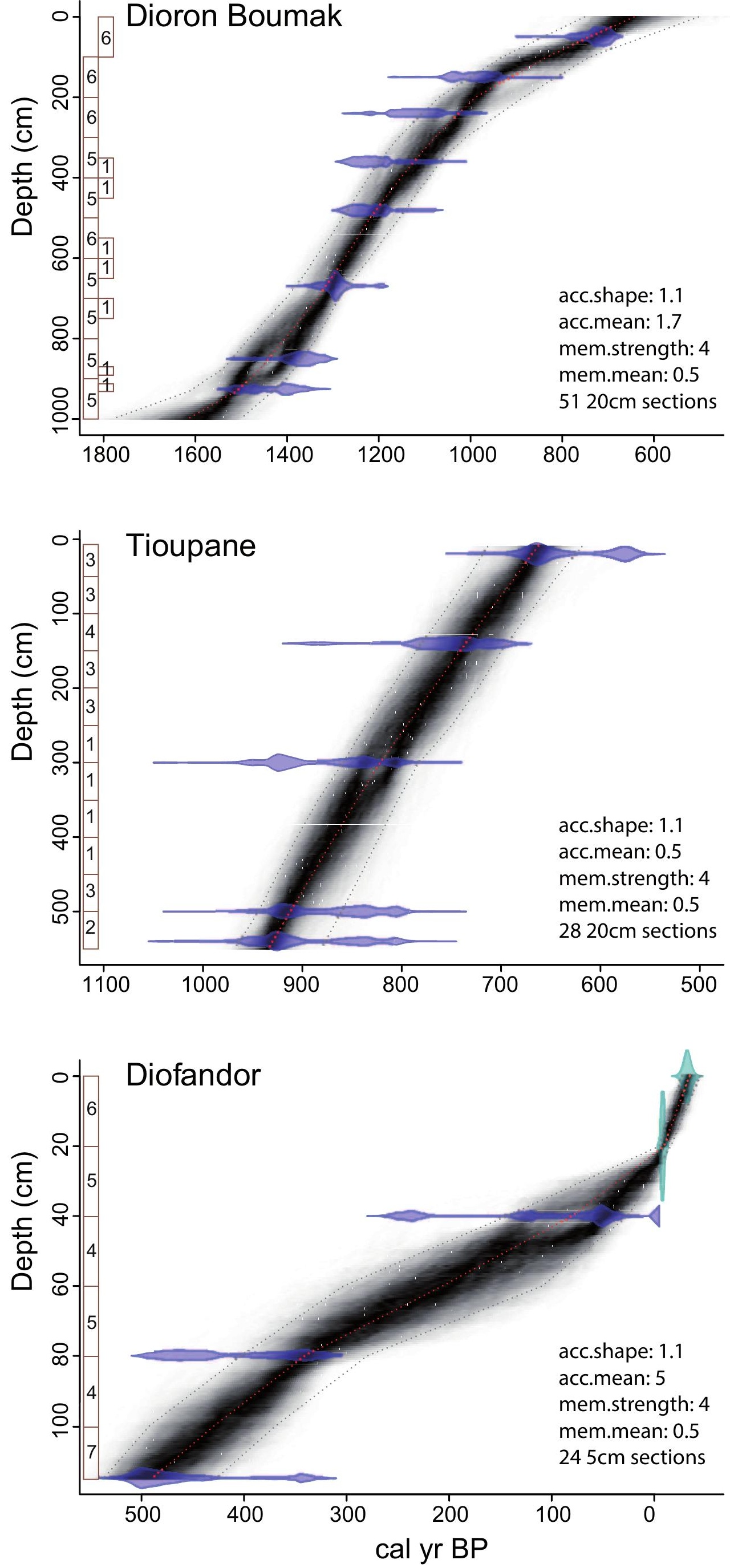


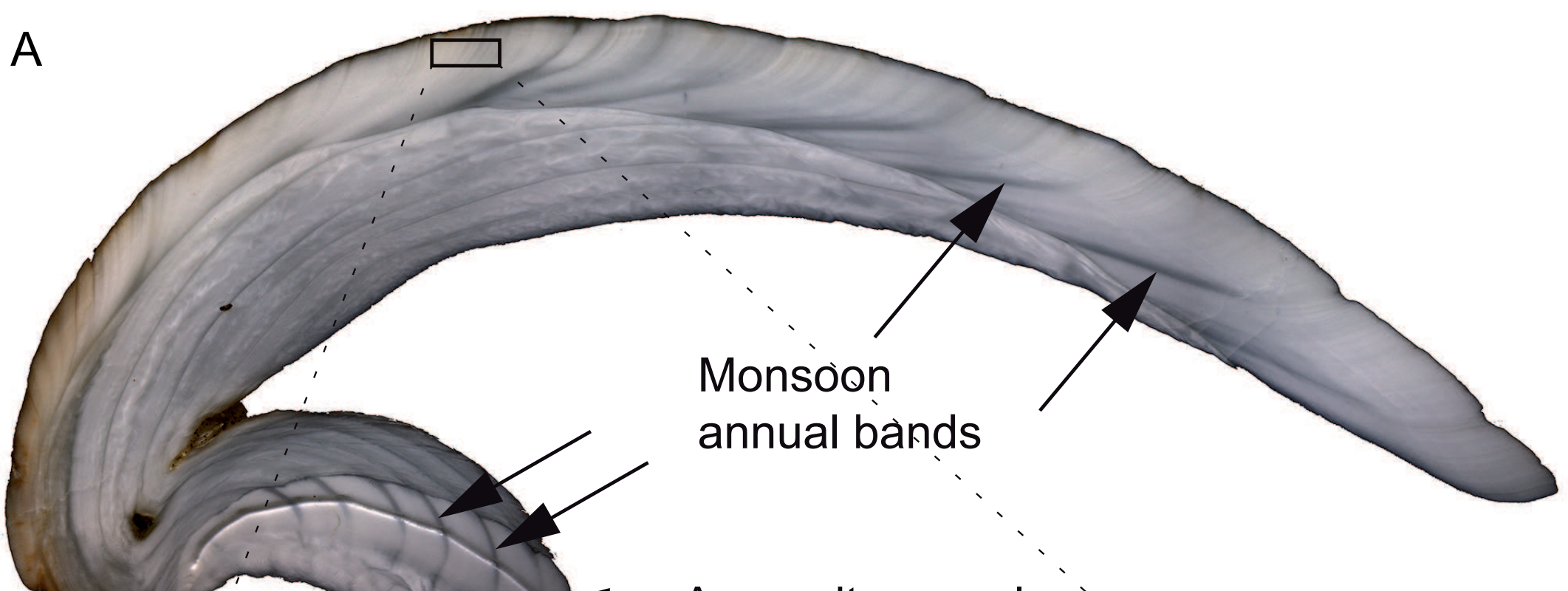

B

Half /unar month
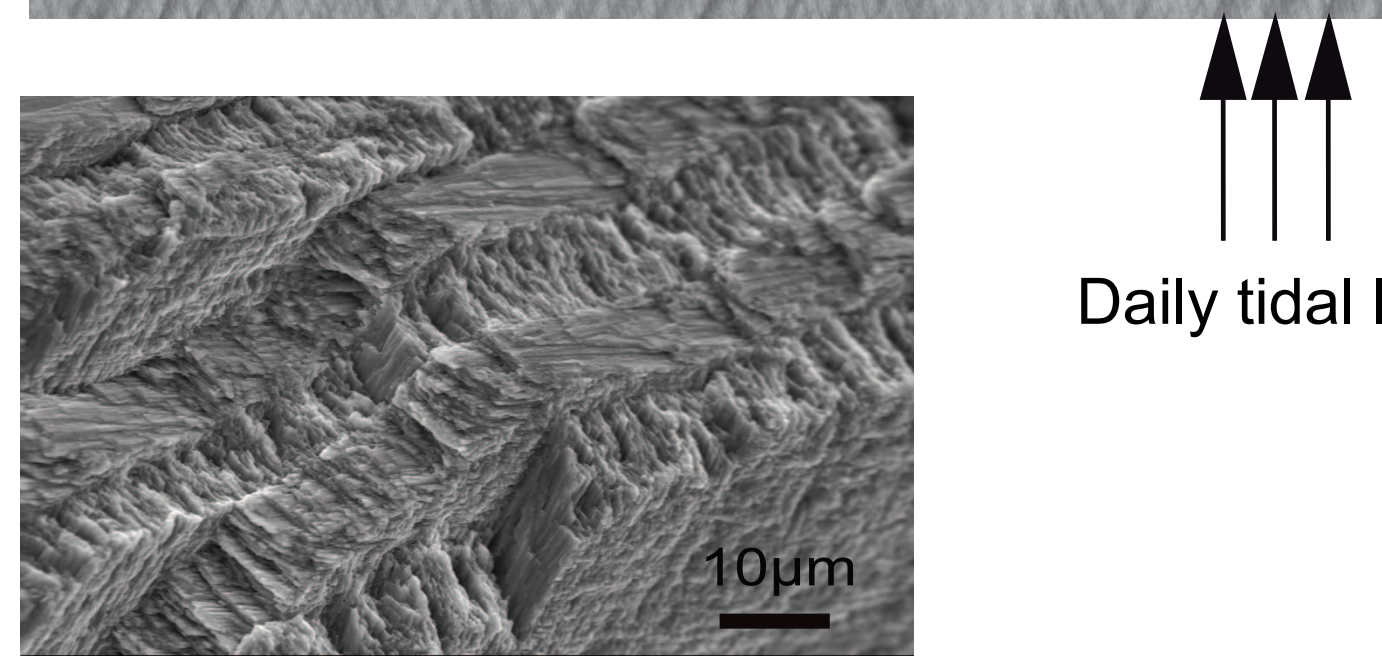

$100 \mu m$

C

Daily tidal lines 
$\left.\begin{array}{ll}\text { A } & -5 \\ & -4\end{array}\right]$ Shell $\delta 18$ Oarag. Toubakouta

B
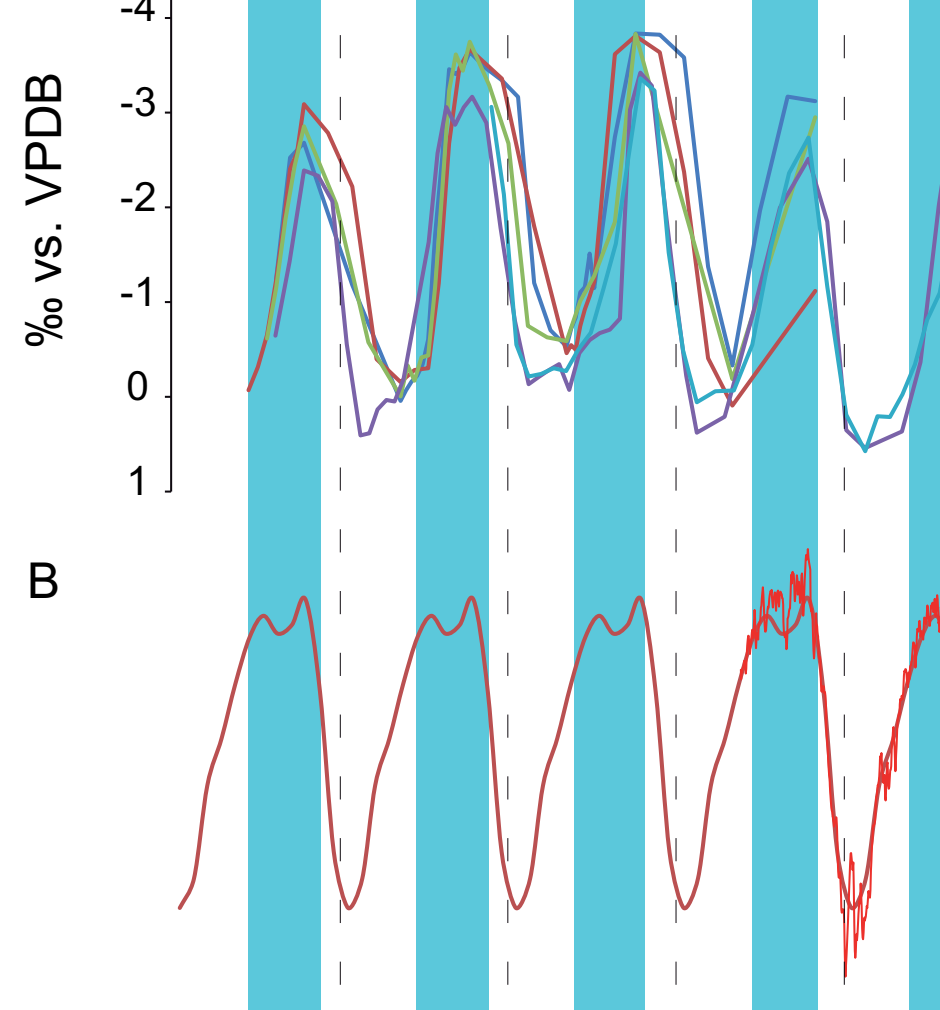

C $\quad-2$ Measured $\delta^{18} \mathrm{O}_{\mathrm{w}}$ in Toubakouta

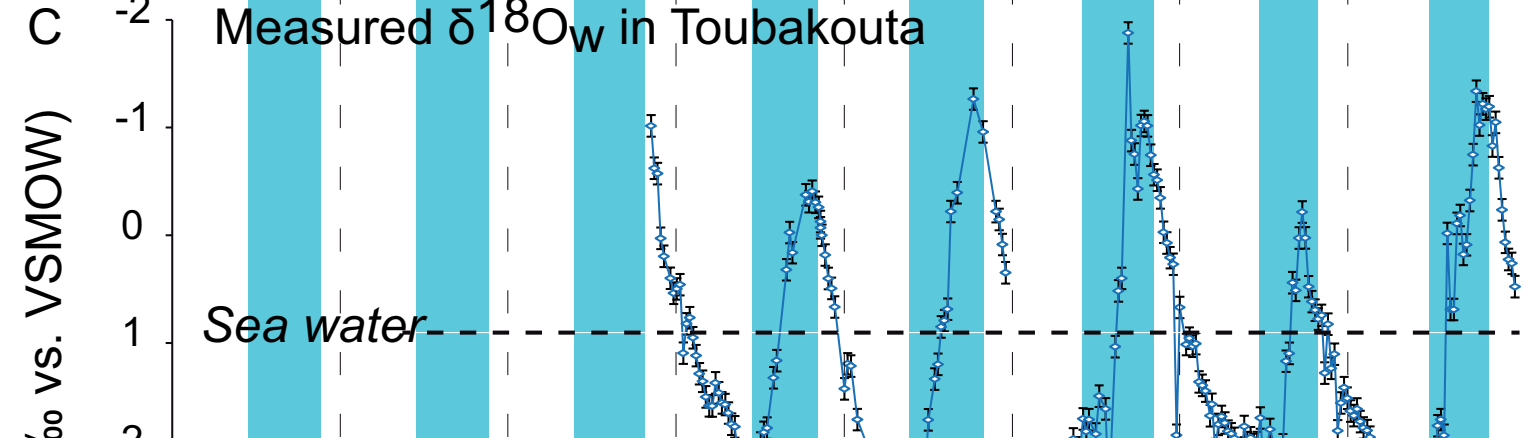

D

E 500

$\therefore$

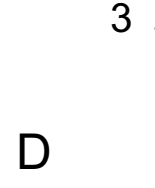

$\overbrace{\text { ह }}^{400} 300$
口 200 


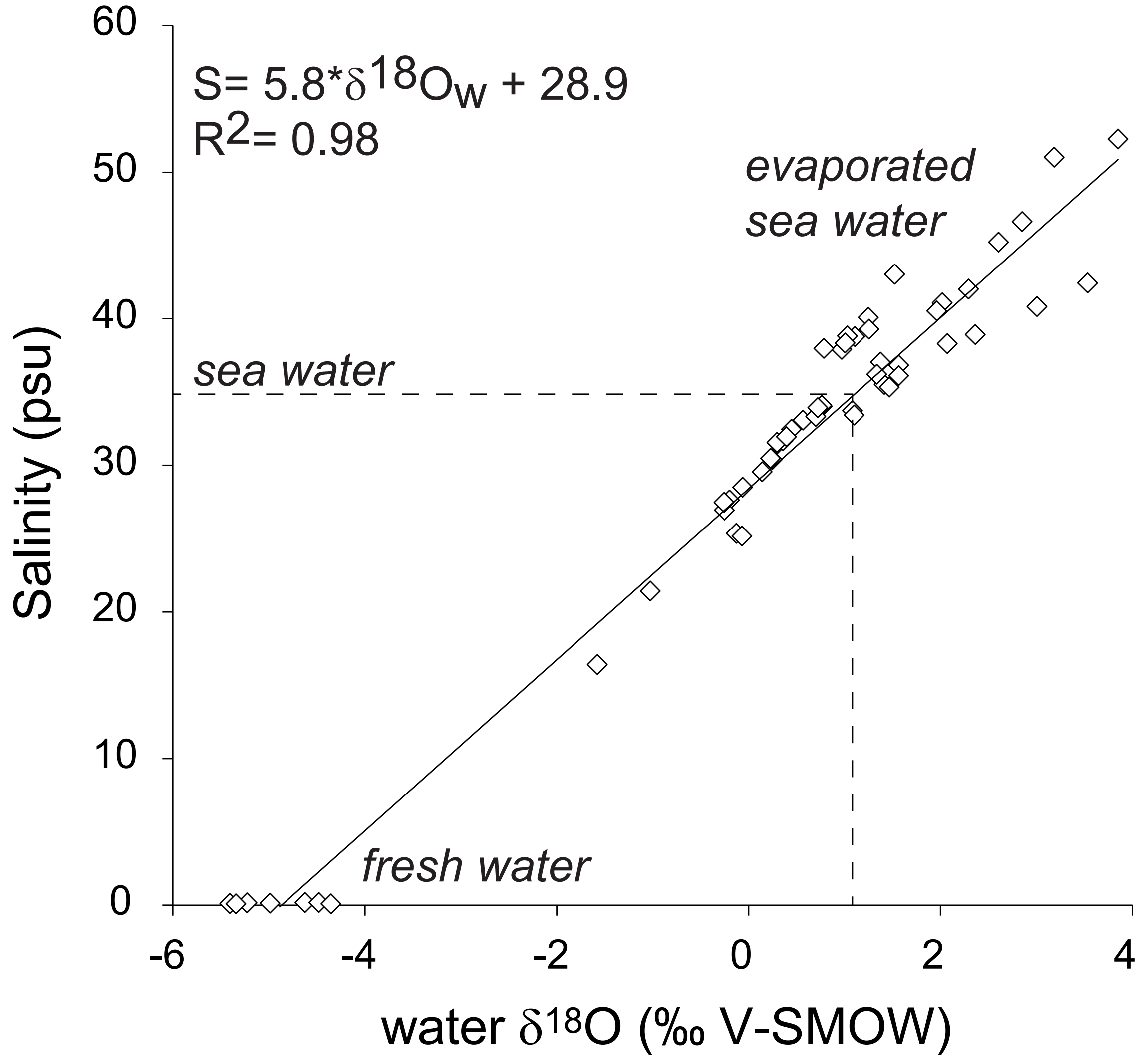




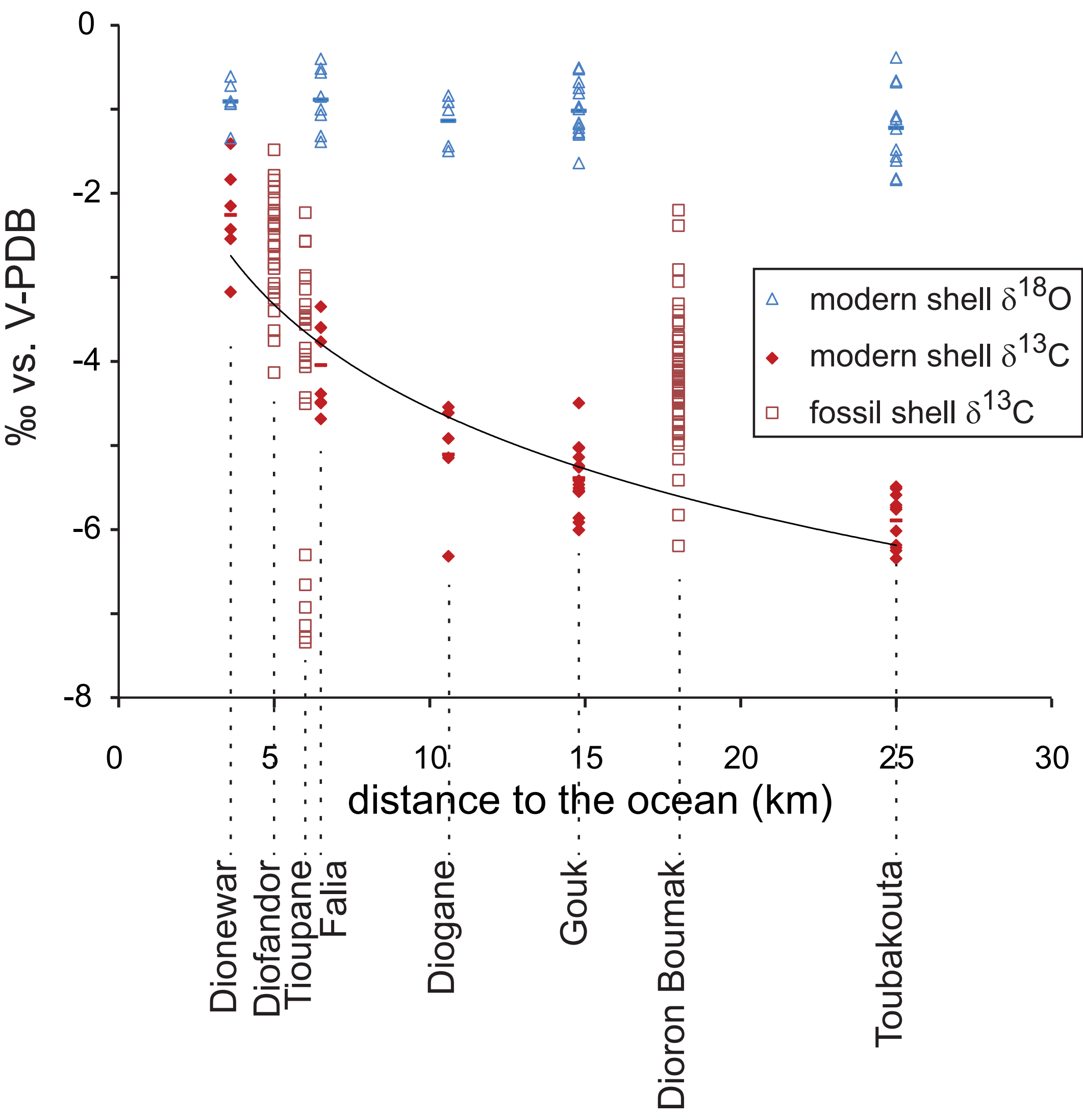




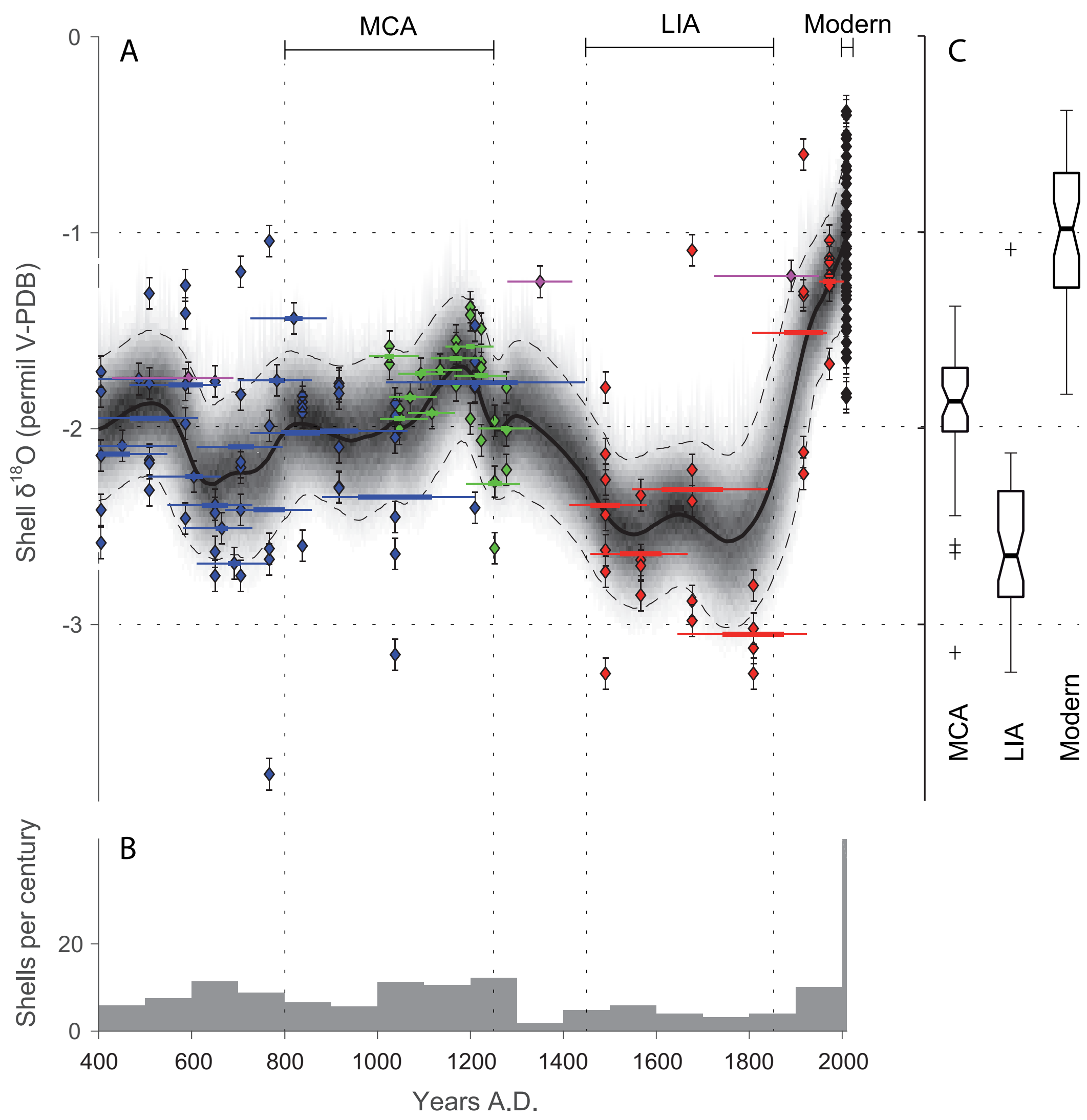


$\triangle-$ Modern shells (collected live)

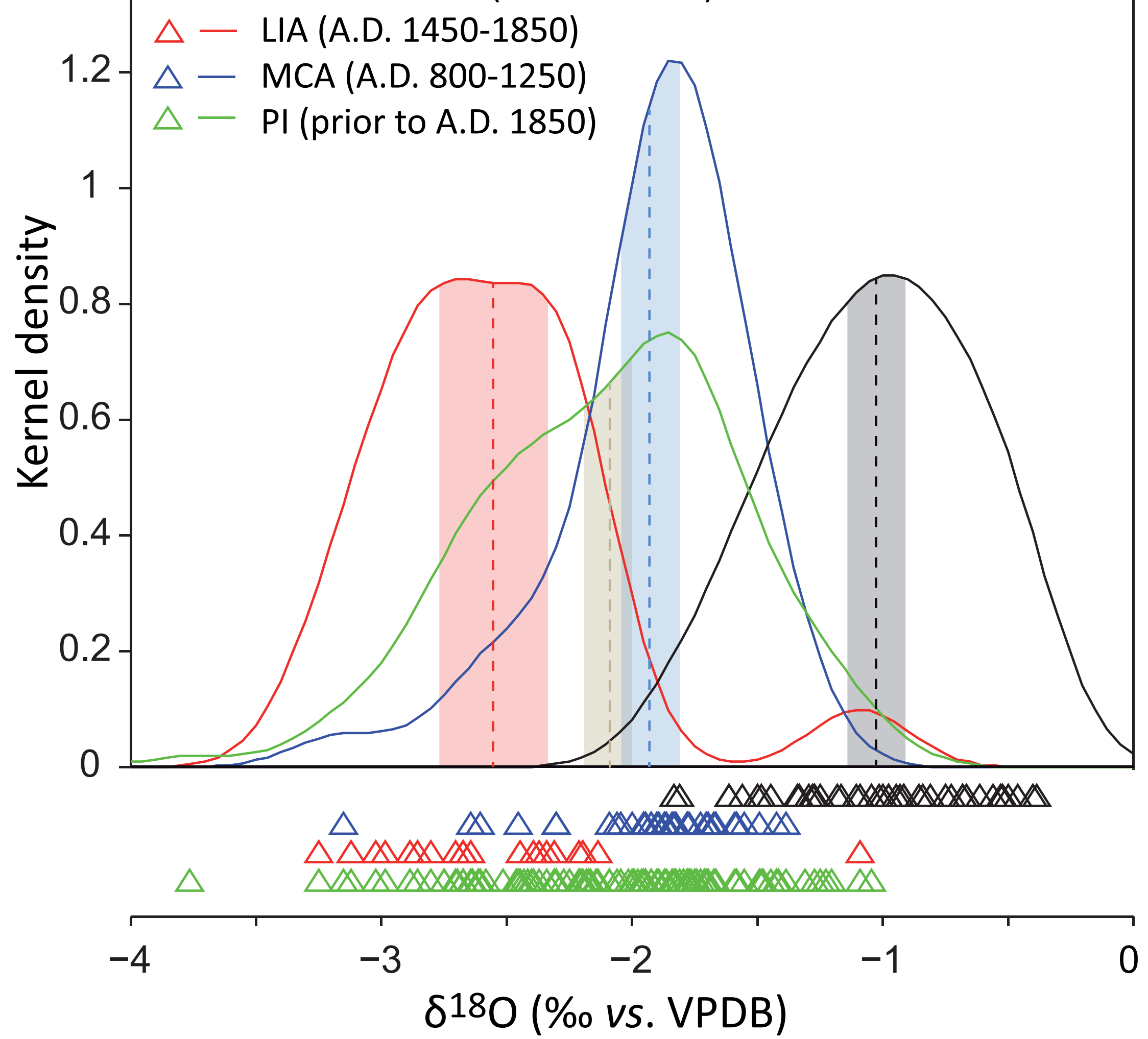



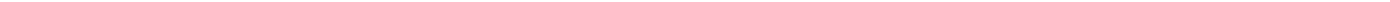
Table 1. Radiocarbon dates and calibration

\begin{tabular}{|c|c|c|c|c|c|c|c|c|c|}
\hline Site & Material & Lab. Ref. & $\begin{array}{l}\text { Depth } \\
(\mathrm{cm})\end{array}$ & $\begin{array}{l}\delta^{13} \mathrm{C}(\% \\
\text { VPDB) }\end{array}$ & $\begin{array}{c}{ }^{14} \mathrm{C} \text { age / } \\
\mathrm{F}^{14} \mathrm{C}\end{array}$ & $\begin{array}{c}\text { Calibration } \\
\text { dataset }\end{array}$ & $\begin{array}{l}\text { \%mar. } \\
\text { carbon }\end{array}$ & $\begin{array}{c}\text { Cal. } \\
\text { median } \\
(A D)\end{array}$ & $2 \sigma$ range \\
\hline \multirow[t]{4}{*}{ Diofandour } & charcoal & UBA-29457 & 20 & $-25^{\star}$ & $\begin{array}{c}1.0921 \\
\pm 0.0044\end{array}$ & $\mathrm{NHZ2}$ & & 1957 & $1957-1958^{* * *}$ \\
\hline & charcoal & SacA 25602 & 40 & -25.3 & $35 \pm 30$ & IntCal13 & & 1893 & 1695-1955 \\
\hline & charcoal & UBA-29458 & 80 & $-25^{\star}$ & $363 \pm 26$ & IntCal13 & & 1519 & $1451-1633$ \\
\hline & charcoal & SacA 25603 & 115 & -25.9 & $415 \pm 30$ & IntCal13 & & 1463 & $1429-1618$ \\
\hline \multirow[t]{5}{*}{ Tioupane } & charcoal & SacA 25604 & 20 & -31.4 & $690 \pm 35$ & IntCal13 & & 1294 & $1262-1390$ \\
\hline & charcoal & SacA37940 & 140 & -26.6 & $840 \pm 30$ & IntCal13 & & 1203 & 1059-1264 \\
\hline & charcoal & SacA25605 & 300 & -24.1 & $985 \pm 30$ & IntCal13 & & 1047 & $991-1154$ \\
\hline & charcoal & SacA 25606 & 500 & -24.4 & $970 \pm 30$ & IntCal13 & & 1089 & $1017-1155$ \\
\hline & charcoal & SacA 25607 & 540 & -22.9 & $995 \pm 30$ & IntCal13 & & 1031 & $986-1153$ \\
\hline \multirow[t]{8}{*}{$\begin{array}{c}\text { Dioron } \\
\text { Boumak } \\
\end{array}$} & charcoal & UBA 19943 & 50 & $-25^{\star}$ & $817 \pm 23$ & IntCal13 & & 1229 & $1179-1265$ \\
\hline & charcoal & UBA 19944 & 150 & $-25^{*}$ & $1083 \pm 38$ & IntCal13 & & 957 & 890-1019 \\
\hline & charcoal & SacA 25596 & 240 & -24.2 & $1195 \pm 35$ & IntCal13 & & 829 & $694-947$ \\
\hline & charcoal & SacA 25597 & 360 & -25.9 & $1260 \pm 30$ & IntCal13 & & 736 & $669-862$ \\
\hline & charcoal & SacA 25598 & 480 & -19.8 & $1270 \pm 30$ & IntCal13 & & 729 & $664-856$ \\
\hline & charcoal & SacA 25599 & 670 & -23 & $1370 \pm 30$ & IntCal13 & & 655 & $608-688$ \\
\hline & charcoal & SacA 25600 & 850 & -24.8 & $1480 \pm 30$ & IntCal13 & & 587 & $541-642$ \\
\hline & charcoal & SacA 25601 & 925 & -20.8 & $1530 \pm 30$ & IntCal13 & & 537 & $432-600$ \\
\hline A-10 & shell & SacA37929 & 0 & -7.1 & $340 \pm 30$ & Mixed ** & 72 & 1890 & 1725-1955 \\
\hline$A-12$ & shell & SacA37930 & 0 & -9.1 & $950 \pm 30$ & Mixed ** & 64 & 1350 & $1286-1415$ \\
\hline$A-49$ & shell & SacA37922 & 0 & -2.1 & $1885 \pm 30$ & Mixed ** & 92 & 593 & $454-686$ \\
\hline
\end{tabular}

*assumed value

${ }^{* *}$ mixed using IntCal13 and Marine13 with $\Delta \mathrm{R}=0$. Marine carbon percentage was estimated from $\delta^{13} \mathrm{C}$ value assuming a $0 \%$ ovalue for the marine endmember and a $-25 \%$ o value for the terrestrial carbon endmember.

$* * *$ the 1997-2002 interval was excluded from the calibration because the site was abandoned in 1982. 